OPEN ACCESS

Edited by:

Joshua K. S. Ko,

Hong Kong Baptist University,

Hong Kong

Reviewed by:

Ali Hussein Eid,

American University of Beirut,

Lebanon

Wentzel Christoffel Gelderblom,

Cape Peninsula University of

Technology, South Africa

*Correspondence:

Ling-Dong Kong

kongld@nju.edu.cn

tThese authors have contributed equally to this work

Specialty section:

This article was submitted to

Ethnopharmacology,

a section of the journal

Frontiers in Pharmacology

Received: 24 July 2018

Accepted: 15 October 2018

Published: 06 November 2018

Citation:

Zhang Q-Y, Wang F-X, Jia K-K and Kong L-D (2018) Natural Product Interventions for Chemotherapy and Radiotherapy-Induced Side Effects.

Front. Pharmacol. 9:1253.

doi: 10.3389/fphar.2018.01253

\section{Natural Product Interventions for Chemotherapy and Radiotherapy-Induced Side Effects}

\author{
Qing-Yu Zhang ${ }^{1+}$, Fei-Xuan Wang ${ }^{2 \dagger}$, Ke-Ke Jia ${ }^{3}$ and Ling-Dong Kong ${ }^{3 *}$ \\ ${ }^{1}$ School of Medicine and Life Sciences, Nanjing University of Chinese Medicine, Nanjing, China, ${ }^{2}$ Department of Pathology, \\ Sir Run Run Hospital, Nanjing Medical University, Nanjing, China, ${ }^{3}$ State Key Laboratory of Pharmaceutical Biotechnology, \\ School of Life Sciences, Nanjing University, Nanjing, China
}

Cancer is the second leading cause of death in the world. Chemotherapy and radiotherapy are the common cancer treatments. However, the development of adverse effects resulting from chemotherapy and radiotherapy hinders the clinical use, and negatively reduces the quality of life in cancer patients. Natural products including crude extracts, bioactive components-enriched fractions and pure compounds prepared from herbs as well as herbal formulas have been proved to prevent and treat cancer. Of significant interest, some natural products can reduce chemotherapy and radiotherapy-induced oral mucositis, gastrointestinal toxicity, hepatotoxicity, nephrotoxicity, hematopoietic system injury, cardiotoxicity, and neurotoxicity. This review focuses in detail on the effectiveness of these natural products, and describes the possible mechanisms of the actions in reducing chemotherapy and radiotherapy-induced side effects. Recent advances in the efficacy of natural dietary supplements to counteract these side effects are highlighted. In addition, we draw particular attention to gut microbiotan in the context of prebiotic potential of natural products for the protection against cancer therapy-induced toxicities. We conclude that some natural products are potential therapeutic perspective for the prevention and treatment of chemotherapy and radiotherapy-induced side effects. Further studies are required to validate the efficacy of natural products in cancer patients, and elucidate potential underlying mechanisms.

Keywords: natural products, cancer, chemotherapy, radiotherapy, side effects

\section{INTRODUCTION}

Cancer is one of the most common causes of death worldwide (Mcguire, 2016). Chemotherapy and radiotherapy are the most effective and extensive approaches for cancer management. However, chemotherapy, and radiotherapy-induced adverse effects including oral mucositis, gastrointestinal toxicity, hepatotoxicity, nephrotoxicity, hematopoietic system injury, cardiotoxicity, and neurotoxicity, hinder the clinical uses. Subsequently, these harmful effects often reduce the quality of life in cancer patients, and may lead to therapy discontinuation (Shapiro, 2016; Turcotte et al., 2017). Therefore, it is important to develop effective management strategies against chemotherapy and radiotherapy-induced side effects.

Natural products including crude extracts, bioactive components-enriched fractions, and pure compounds derived from herbs as well as herbal formulas have been proved to prevent and treat cancers (Sanders et al., 2016). Clinical trials and preclinical studies show that some natural products 
can reduce chemotherapy and radiotherapy-induced oral mucositis, gastrointestinal toxicity, hepatotoxicity, nephrotoxicity, hematopoietic system injury, cardiotoxicity, and neurotoxicity. Natural dietary supplements containing some ingredients such as Ginseng extract, Grape seed extract, and curcumin promote the recovery from severe illness, and relieve chemotherapy and radiotherapy-induced side effects. Gut microbiota plays the role in the modulation of drug action (Curro, 2018), possibly could evaluate the risk of severe gastrointestinal toxicity. Herb medicine has potential to improve digestive health (Peterson et al., 2018). The aim of this review is to summarize the recent evidence in detail for the effectiveness of natural products, and describe the possible mechanisms of the actions in reducing chemotherapy and radiotherapy-induced side effects. This review also draws particular attention to recent advances in the efficacy of natural dietary supplements, and the modulation of natural products on gut microbiotan for the protection against cancer therapy-induced toxicity.

\section{PREVENTION OF ORAL MUCOSITIS PARTLY BY REDUCING OXIDATIVE STRESS, INFLAMMATION, AND INFECTION}

Oral mucositis is a common complication in patients undergoing chemotherapy and radiotherapy, which is initiated partly by oxidative stress and inflammation. Plant-derived and other natural medicines with anti-inflammation are recently demonstrated to manage chemotherapy-induced oral mucositis (Panahi et al., 2016; Mahendran et al., 2018). Plantago major is a most abundant herbaceous perennial plant that has been traditionally used for hundreds of years, and is effective as a wound healer with anti-ulcerative, anti-inflammatory, antibacterial, anti-viral, and anti-oxidant activities (Adom et al., 2017). Moreover, its extract is reported to have anticancer effect in Ehrlich ascites tumor bearing Balb/C mice (Ozaslan et al., 2007). A feasibility randomized triple-blind phase III clinical trial shows that $P$. major extract, chlorhexidine $0.12 \%$ and sodium bicarbonate $5 \%$ solution can effectively manage oral mucositis in cancer patients with grade II-III mucositis (Cabrera-Jaime et al., 2018).

Severe stomatitis may interrupt or discontinue cancer therapeutics, and increase the risk of local and systemic infection. Japanese traditional medicine (Kampo) Hangeshashinto (TJ14) effectively relieves chemotherapy-induced oral mucositis in gastric cancer and colorectal cancer patients by antioxidation and anti-inflammation (Matsumoto et al., 2015; Nishikawa et al., 2018) or suppression of inflammatory cell chemotaxis and cyclooxygenase-2 (COX2) expression (Kamide et al., 2017). Chamomile (Matricaria recutita) is a medicinal plant widely used in traditional medicine for its anti-oxidant, anti-microbial, and anti-inflammatory actions (Gomes et al., 2018), which seems to be a promising alternative for the treatment of 5-fluorouracil-induced oral mucositis and recurrent aphthous stomatitis (Seyyedi et al., 2014; Gomes et al., 2018). Aznol mouthwash combined with chamomile extract and
Hangeshashinto, alleviates stomatitis in a small cohort of lung cancer patients treated with afatinib (Kato et al., 2017). Aloe vera, an herbal medicine in tropical area, has been used to treat skin disorders with anti-bacterial and wound-healing effects. Its mouthwash significantly reduces the intensity of chemotherapyinduced stomatitis and pain in clients with lymphoma and leukemia, and possibly improves the nutritional status of cancer patients (Mansouri et al., 2016).

Natural nutritional products are also investigated to reduce chemotherapy and radiotherapy-induced oral mucositis. Turmeric (the rhizome of Curcuma longa) is a traditional spice and herb with many health benefits. Turmeric and its active ingredient curcumin have anti-oxidant and antiinflammatory properties. Anticancer effects of curcumin have been demonstrated in a number of preclinical studies as well as in phase I/II clinical trials (Hatcher et al., 2008). Curcumin mouthwash is observed to be better than chlorhexidine mouthwash in terms of rapid wound healing in adult patients with chemotherapy and radiotherapy-induced oral mucositis (Patil et al., 2015). The rhizome of Zingiber officinale (ginger) is also used as traditional medicine with health benefits to treat muscular aches and pains worldwide. Its main ingredients 6-gingerol and 6-shogaol are reported to relief 5-fluorouracilinduced oral ulcerative mucositis and pain by regulating $\mathrm{Na}^{+}$channels, playing an essential role in ginger-associated analgesia of pain (Hitomi et al., 2017). Tocotrienols are natural compounds existed in vegetable oil, which are a promising analogs of vitamin $\mathrm{E}$ for cancer therapeutics by sensitizing cancer cells to chemotherapeutic agents (Sailo et al., 2018). $\gamma$-Tocotrienol can prevent 5-fluorouracil-induced reactive oxygen species (ROS) generation in human oral keratinocytes by stabilizing the activation of nuclear factor erythroid 2related factor 2 (Nrf2), a redox-sensitive master regulatory transcription factor (Takano et al., 2015). Quercetin, a natural flavonoid enriched in common vegetables and herbs, has anti-oxidative and anti-inflammatory effects. Administered $250 \mathrm{mg}$ quercetin capsules twice daily for 4 weeks, can reduce the incidence of oral mucositis in patients who undergo high dose chemotherapy for blood malignancy (Kooshyar et al., 2017).

Honey produced by bees from flower nectar, is a folk medicine since ancient times in many countries. A metaanalysis indicates that honey can effectively reduce the incidence of chemotherapy and radiotherapy-induced oral mucositis (Xu et al., 2016). Further clinical evidence demonstrates its effectiveness as a preventative and therapeutic measure for chemotherapy-associated oral mucositis in pediatric oncology patients (Friend et al., 2018). There is potential interaction between oral microenvironment and mucositis development. Honey treatment produces the significant reduction of oral mucositis associated Candida and aerobic pathogenic bacterial infection, and increases body weight, delays the onset of oral mucositis, and decreases the severity of pain (Al Jaouni et al., 2017). In Turkey, black mulberry molasses is a foodstuff widely used as traditional intervention for the treatment of mucositis. Recently, black mulberry molasses usage is demonstrated to be an effective intervention in the prevention of radiation-induced 
oral mucositis in head and neck cancer patients (Demir Dogan et al., 2017). Propolis is a natural product collected by honeybee worker, and contains flavonoids with anti-ulcer, anti-bacterial, anti-fungal, healing and anti-inflammatory effects (Dodwad and Kukreja, 2011). Its water extract mouthwash efficiently prevents and heals chemotherapy or radiotherapy-induced oral mucositis in patients with head and neck cancers, or leukemia (Javadzadeh Bolouri et al., 2015; Eslami et al., 2016). However, early report of a double blind randomized placebo controlled trial shows that propolis cannot be recommended for severe oral mucositis in chemotherapy-treated pediatric patients (Tomazevic and Jazbec, 2013). The natural products in this part together with relevant characteristics of the respective studies are summarized in Table 1.

\section{MITIGATION OF GASTROINTESTINAL TOXICITY BY REGULATING GASTROINTESTINAL FUNCTION AND GUT MICROBIOTA}

The most common gastrointestinal toxicities induced by chemotherapy and radiotherapy include nausea, vomiting and diarrhea. In 2016, Chen et al. conduct a systematic review and meta-analysis (from 2005 to 2013) and show that Atractylodes macrocephala, Poria cocos, Coix lacryma-jobi, Astragalus membranaceus, Glycyrrhiza uralensis, and Panax ginseng can significantly reduce oxaliplatin-induced nausea and vomiting in colorectal cancer (Chen M. H. et al., 2016). Bacopa monnieri is used in several traditional systems of medicines for the management of epilepsy, depression, and neuropathic pain. Its bacoside-rich n-butanol fraction antagonizes cisplatininduced retching and vomiting response (Ullah et al., 2017). Red Ginseng, a product with a steaming and drying process of the fresh ginseng, contains the majority of ginsenosides. Its anticancer mechanisms mainly include cell cycle arrest, apoptosis/paraptosis induction, and angiogenesis inhibition (Wang et al., 2016). Recently, a randomized double blind placebo-controlled trial demonstrates that Red Ginseng decreases symptom of nausea, vomiting, dyspnea and fatigue, and its efficacy and safety can improve life quality in patients receiving six cycles of adjuvant taxane- and platinum-based chemotherapy after cytoreductive surgery (Kim H. S. et al., 2017). A phase II randomized double-blind placebo-controlled study shows that safe and well-tolerated 6-gingerol improves the overall complete response rate in nausea and vomiting, appetite as well as quality of life in cancer patients with surgical resection of primary tumor and moderately to highly emetogenic adjuvant chemotherapy (Konmun et al., 2017), further demonstrating that ginger supplementation can significantly reduce the severity of chemotherapy-induced nausea in adult cancer patients (Ryan et al., 2012). Rhus coriaria, a flowering shrub, possesses anticancer effect against human colorectal cancer cells and triple-negative breast cancer cells (El Hasasna et al., 2015, 2016; Athamneh et al., 2017). Its resin extract also attenuates angiogenesis and is used in treatment and management of cancer in Kenya (Ochwang'i et al., 2014; Mirian et al., 2015). Bunium persicum is a perennial plant in Iran. A randomized, double blind, crossover clinical trial shows that Persumac, a combination of $R$. coriaria and B. persicum, may be helpful in patients with refractory chemotherapy-induced nausea and vomiting (Nazari et al., 2017).

Huang-Qin decoction is first described in Chinese canonical medicine about 1800 years ago for the treatment of different gastrointestinal symptoms, including nausea, vomiting and diarrhea. This decoction attenuates irinotecan-induced gastrointestinal toxicity and diarrhea in rats possibly via regulating glycine, serine and threonine pathway as well as bile acid metabolism homeostasis. Scutelleria baicalensis may play a crucial role in the therapeutic effect of this decoction on irinotecan-induced diarrhea (Cui et al., 2017; Wang X. et al., 2017).

Of note, nutrient absorption and digestion of gastrointestinal tract may be compromised during chemotherapy and radiotherapy-induced damage to non-cancerous gastrointestinal mucosa. In 2018, Mahendran et al. review and show that plantderived and some natural medicines with anti-inflammation manage chemotherapy-caused gastrointestinal mucositis (Mahendran et al., 2018). Other animal experiments confirm the efficacy of herbal medicines on intestinal mucositis. Wei-ChangAn pill, a traditional Chinese pharmaceutical preparation, possesses anti-inflammatory advantage and gastrointestinal regulation in digestive diseases. This pill promotes the recovery of intestinal function in 5-fluorouracil-induced intestinal mucositis in mice via relieving severe diarrhea and inhibiting gastric emptying and gastrointestinal transit in intestinal homeostasis (Chen Y. et al., 2016). Bu-Zhong-Yi-Qi decoction, a Chinese traditional herbal medicine, is widely used in Asia as an alternative treatment to reduce side effects of chemotherapy. This decoction protects against 5-fluorouracil-induced intestinal mucositis in mice (Gou et al., 2016). Saireito (TJ-114) is often used to treat inflammatory diseases such rheumatoid arthritis, systemic lupus erythematodes, and nephrotic syndrome. TJ-114 can reduce 5-fluorouracil-induced intestinal mucositis in mice by inhibiting cytokine-mediated apoptosis in intestinal crypt cells (Kato et al., 2015). The root of Rehmannia glutinosa is one of the commonly used Chinese herbal medicines. Its steamed products alleviate methotrexate-induced rat gut mucositis by inhibiting oxidative stress and inflammation (Shi et al., 2016). Licorice (G. uralensis) is reported to possess anti-tumor activity, and effectively treats peptic ulcer. Its pentacyclic triterpenoid derivative $18 \beta$-glycyrrhetinic acid has anti-inflammatory, hepatoprotective and anti-oxidant effects. This compound prevents against cisplatin-induced oxidative intestinal damage in rats possibly by inhibiting nuclear factorkappa B (NF- $\mathrm{kB}$ ) and caspases (Rashid et al., 2017). Rutin with free radical scavenging and anti-inflammatory actions also significantly protects against methotrexate-induced intestinal lesion damage in rats (Gautam et al., 2016). Nigella sativa seed is a traditional herbal medicine throughout the world. Its oil is beneficial in a wide range of gastrointestinal disorders, and significantly attenuates cisplatin-induced alteration of brush border membrane enzymes, carbohydrate metabolism and antioxidant system in the intestine of rats (Shahid et al., 2017b). Thymoquinone, a major principle active ingredient derived from this seed oil, improves gastrointestinal function as well as 
TABLE 1 | Natural products in reducing chemotherapy and radiotherapy-induced oral mucositis.

\begin{tabular}{|c|c|c|c|c|}
\hline Name & Effect/Mechanism & $\begin{array}{l}\text { Experimental } \\
\text { setting/Model }\end{array}$ & Ingredients/Source & References \\
\hline P. major & Anti-inflammation & Patients & $\begin{array}{l}\text { A variety of bioactive compounds including } \\
\text { flavonoids, alkaloids, terpenoids, caffeic } \\
\text { acid derivatives, and iridoid glycosides }\end{array}$ & Cabrera-Jaime et al., 2018 \\
\hline Hangeshashinto & $\begin{array}{l}\text { Anti-oxidation and } \\
\text { anti-inflammation }\end{array}$ & Patients & $\begin{array}{l}\text { Made from Pinelliae tuber, Scutellariae } \\
\text { radix, Glycyrrhizae radix, Zizyphi fructus, } \\
\text { Ginseng radix, Zingiberis Processum } \\
\text { rhizoma, and Coptidis rhizome } \\
\text { Main chemical constituents: baicalin, } \\
\text { baicalein, wogonin, acteoside, berberine } \\
\text { chloride, coptisine, [6]-shogaol, } \\
\text { [6]-gingerol, liquiritin, glycyrrhizic acid, } \\
\text { ginsenoside Rg1, ginsenoside Rb1, } \\
\text { corymboside, and homogentisic acid }\end{array}$ & $\begin{array}{l}\text { Matsumoto et al., 2015; } \\
\text { Kamide et al., 2017; } \\
\text { Nishikawa et al., } 2018\end{array}$ \\
\hline Chamomile & $\begin{array}{l}\text { Anti-oxidation, anti-microbial, } \\
\text { and anti-inflammation }\end{array}$ & Patients & $\begin{array}{l}\text { Terpenoids, favonoids, coumarins, } \\
\text { alkaloids, polysaccharides, and glycoside } \\
\text { derivatives }\end{array}$ & $\begin{array}{l}\text { Seyyedi et al., 2014; Gomes } \\
\text { et al., } 2018\end{array}$ \\
\hline A. vera & $\begin{array}{l}\text { Improvement of the nutritional } \\
\text { status }\end{array}$ & Patients & $\begin{array}{l}\text { Oleic acid, tannin, saponin, flavonoids, } \\
\text { and terpenoids }\end{array}$ & Mansouri et al., 2016 \\
\hline Curcumin & $\begin{array}{l}\text { Anti-oxidation, anti-inflammation } \\
\text { and anti-cancer }\end{array}$ & Patients & Bioactive constituent of Curcuma longa L. & Patil et al., 2015 \\
\hline Ginger & Regulation of $\mathrm{Na}^{+}$channels & Patients & 6-gingerol and 6-shogaol & Hitomi et al., 2017 \\
\hline$\gamma$-Tocotrienols & $\begin{array}{l}\text { Prevention of ROS generation by } \\
\text { stabilizing Nrf2 activation }\end{array}$ & Patients & Analogues of the vitamin $E$ & Takano et al., 2015 \\
\hline Quercetin & $\begin{array}{l}\text { Anti-oxidation and } \\
\text { anti-inflammation }\end{array}$ & Patients & Rich in daily vegetables and herbs & Kooshyar et al., 2017 \\
\hline Honey & $\begin{array}{l}\text { Reduction of oral mucositis } \\
\text { associated Candida and aerobic } \\
\text { pathogenic bacterial infection }\end{array}$ & Patients & $\begin{array}{l}\text { Glucose, fructose, acids, proteins, } \\
\text { minerals, and polyphenols }\end{array}$ & $\begin{array}{l}\text { Xu et al., 2016; Al Jaouni } \\
\text { et al., 2017; Friend et al., } \\
2018\end{array}$ \\
\hline $\begin{array}{l}\text { Black } \\
\text { mulberry } \\
\text { molasses }\end{array}$ & Antimicrobial & Patients & Phenolics and fatty acids & Demir Dogan et al., 2017 \\
\hline Propolis & $\begin{array}{l}\text { Not be recommended for severe } \\
\text { oral mucositis }\end{array}$ & Patients & $\begin{array}{l}\text { A natural product collected by honeybee } \\
\text { worker }\end{array}$ & $\begin{array}{l}\text { Tomazevic and Jazbec, } \\
\text { 2013; Javadzadeh Bolouri } \\
\text { et al., 2015; Eslami et al., } \\
2016\end{array}$ \\
\hline
\end{tabular}

the redox and metabolic status of intestinal mucosal tissue in rat model of cisplatin-induced intestinal injury (Shahid et al., 2017a).

Radiotherapy-induced esophagitis and enteropathy are the major issues for long-term cancer survivors (Kim J. S. et al., 2017). Chinese herbal medicine Zhu-Ye-Shi-Gao granule can treat recurrent oral ulcer and chronic pharyngitis. A randomized controlled trial shows that this granule decreases the incidence and grade of acute radiation-induced esophagitis, demonstrating its efficacy and safety in patients with lung, esophagus or mediastinal cancer (Wang L. J. et al., 2017). A. vera also effectively treats acute radiation proctitis in patients after external-beam radiation therapy of pelvic malignancy (Sahebnasagh et al., 2017). Oroxylin is a natural flavonoid isolated from S. baicalensis, and shows its anticancer effect on human primary hepatocellular carcinoma cells and patient-derived tumor xenograft model for hepatoma (Wei et al., 2017). This compound could be a promising radiosensitizer by inducing $\mathrm{G} 2 / \mathrm{M}$ phase and activating cell apoptosis in esophageal squamous cell carcinoma exposed to radiotherapy (Tan et al., 2017). Grape seed extracts and its proanthocyanidins are commonly utilized as dietary supplements for anti-oxidant property in cancer patients (Bagchi et al., 2014). A systematic review of preclinical studies shows that grape seed extracts may alleviate chemotherapy and radiotherapy-induced toxicity (Olaku et al., 2015). Grape seed proanthocyanidins have radioprotective action (Katiyar et al., 2017; Yang et al., 2017). Green tea contains a high content of catechins. Compared with placebo group, its tablet shows less frequency and severity of radiotherapy-induced diarrhea but not vomiting in patients with abdomen and pelvic malignancy after receiving radiotherapy (Emami et al., 2014). Therefore, an extract mixture of green tea and grape seed is considered to be a good radioprotector and immune modulator, indicating its possible use as an adjuvant during radiotherapy (El-Desouky et al., 2017).

Silymarin, a complex of flavonolignans extracted from milk thistle (Silybum marianum), has been used for centuries as the treatment of different diseases with anti-oxidant and antiinflammatory activities. Its major constituent silibinin is reported 
to radiosensitize prostate cancer by inhibiting DNA repair signaling (Nambiar et al., 2015) and improving the response to radiotherapy in invasive bladder cancer (Prack Mc Cormick et al., 2018). Nephelium lappaceum is an importantly commercial crop with nutrients and bioactive constituents. Its hydrolysable polyphenol geraniin possesses good anti-oxidant property, and protects intestinal crypt cells from $\gamma$-irradiation-induced cell death in mice by suppressing DNA damage, being considered as a radioprotective agent (Bing et al., 2013). Clerodendrum infortunatum rich in flavonoids and saponins is used in Ayurvedic and Siddha traditional medicine. Its hydro-alcoholic extract reduces radiation-induced damage to intestinal crypt cells and suppress BCL2-associated X protein (Bax)/B-cell lymphoma $(\mathrm{Bcl}-2)$ ratio, DNA repair gene ataxia telangiectasia mutated (ATM) and COX-2 gene in mice exposed to whole-body $\gamma$ radiation (Chacko et al., 2017).

The gut microbiota is a vast community of synergistic bacterial species providing health benefits to the host (Westfall et al., 2018). Gastrointestinal tract forms the targets of chemotherapy and radiotherapy-induced toxicity, causing imbalance in the gut microbiota (dysbiosis) (Serban, 2014; Wardill and Tissing, 2017; Bruneau et al., 2018; Curro, 2018). Fucoidans, a group of certain fucose-containing sulfated polysaccharides, are naturally occurring components of certain edible seaweeds and echinoderms in Japan and Korea. Fucoidan intervention can relieve cyclophosphamide-induced intestinal mucosal injury by decreasing inflammation and increasing tight junction protein expression in mice. Low molecular weight of fucoidan $(50 \mathrm{kDa})$ remarkably increases the abundance of short chain fatty acids (SCFAs) producer Coprococcus, Rikenella, and Butyricicoccus species within the intestinal mucosa compared with the cyclophosphamide group, possibly as an effective supplement to protect against intestinal mucosal barrier damage during chemotherapy via gut microbiota (Shi et al., 2017). PHY906 is derived from Huang-Qin-Tang, as a modulator of irinotecanbased chemotherapy in patients with advanced colorectal cancer (Kummar et al., 2011). Of note, intestinal bacteria can metabolize irinotecan and PHY906. In murine Colon-38 tumor-bearing mice, alteration in the population of intestinal bacteria can not affect the ability of PHY906 to enhance irinotecan antitumor activity or reduce irinotecan-induced intestinal toxicity, indicating that the major species of intestinal bacteria may not appear to have a role in the enhancement of the therapeutic index of irinotecan in tumor-bearing mice treated with PHY906 (Lam et al., 2014). SN-38-glucuronide is an active metabolite of irinotecan hydrochloride to be responsible for gastrointestinal toxicity. Interestingly, baicalin, a main constituent in PHY906, is found to reduce intestinal transporter organic anion transporting polypeptide (OATP)1B1-mediated uptake of SN-38, showing its ability to prevent gastrointestinal toxicity (Fujita et al., 2016). Sheng-Jiang-Xie-Xin decoction, a classic traditional Chinese medical formula in Shang Han Lun, has been applied to treat gastroenteritis, ulcerative colitis, and diarrheais, as well as irinotecan-induced gastrointestinal toxicity. Recently, this decoction is reported to alter the pharmacokinetics of irinotecan and its metabolites (SN-38 and SN-38G) to alleviate irinotecaninduced diarrhea in rats, partly by altering carboxylesterase 2 (CES2) and jejunal uridine diphosphate-glucuronosyltransferase
1A1(UGT1A1) activity (Guan et al., 2017). These observations indicate that cancer patients with different gut microbiota profiles may benefit from natural product treatment alongside chemotherapy and radiotherapy. The natural products in this part together with relevant characteristics of the respective studies are summarized in Table 2.

\section{PREVENTION OR INDUCTION OF HEPATOTOXICITY}

Radioembolization-induced liver injury is an uncommon but relevant complication. Lycopene is an anti-oxidant substance in plants and micro-organisms. Its treatment significantly decreases radiotherapy-induced hepatic toxicity with oxidative stress in rats (Meydan et al., 2011). A perennial plant Ashwagandha (Withania somnifera), a perennial plant used in Ayurvedic medicine, shows hepatoprotective and anti-oxidant effects against radiationinduced hepatotoxicity in rats (Hosny Mansour and Farouk Hafez, 2012). N. sativa oil also alleviates irradiation-induced liver injury in rats (Radwan and Mohamed, 2018).

Chemotherapeutic agents commonly cause hepatic injury in cancer patients. Some Indian natural products have promise in relieving chemotherapy-induced hepatotoxicity (Metri et al., 2013). Recently, clinical trials show that milk thistle (main hepatoprotective ingredient silymarin) can effectively reduce hepatotoxicity in oncology patients (Frassova and RudaKucerova, 2017). A edible mushroom mycelium product containing active hexose-correlated compound, can reduce hematotoxicity and hepatotoxicity, and improve the quality of life in patients with advanced cancer during chemotherapy (Ito et al., 2014).

In animals of chemotherapy-induced hepatotoxicity, Pine bark extract $\left(\right.$ Pycnogenol $\left.^{\circledR}\right)$, a standardized proprietary mixture of bioflavonoids extracted from the bark of Pinus pinaster, has protective effect due to its anti-oxidation (Ko et al., 2014). Pomegranate (Punica granatum) is mentioned in the Ebers papyrus of Egypt written in about 1550 BC. Its seed extract containing robust polyphenolic flavonoid can ameliorate cisplatin-induced liver damage in rabbits (Yildirim et al., 2013). Grape seed extract prevents against dexamethasone-induced liver histopathological change in rats (Hasona and Morsi, 2018). Ginsenoside Rg1, a main compound of Ginseng, effectively alleviates cisplatin-induced liver histological lesion in mice possibly by Nrf2 pathway (Gao et al., 2017). Turmeric and curcumin are known to have hepatoprotective action. They antagonize chemotherapy-induced hepatotoxicity (Mohamad et al., 2009; Waseem et al., 2014). Pre-treatment with a combination of curcumin and $\alpha$-tocopherol regulates liver enzyme and lipid peroxidation biomarker, and alleviates liver histopathology change in rats, showing the protection against cisplatin-induced hepatotoxicity via abrogating oxidative stress (Palipoch et al., 2014). Phyllanthus fraternus has long been used in folk medicine to treat liver disturbance and painful disorder. $P$. fraternus attenuates cisplatin and cyclophosphamide-induced mitochondrial damage in rats with hepatotoxicity (Kumari and Setty, 2012). Thus, mitochondria may be considered as the target for the hepatoprotection (Waseem et al., 2017). 
TABLE 2 | Natural products in reducing chemotherapy and radiotherapy-induced gastrointestinal toxicity.

\begin{tabular}{|c|c|c|}
\hline Name & Effect/Mechanism & $\begin{array}{l}\text { Experimental } \\
\text { setting/Model }\end{array}$ \\
\hline B. monnieri & $\begin{array}{l}\text { Prevention of increases } \\
\text { in dopamine in the } \\
\text { brainstem and } \\
\text { increases in 5-HT in the } \\
\text { intestine }\end{array}$ & $\begin{array}{l}\text { Cisplatin-induced } \\
\text { emesis in Suncus } \\
\text { murinus }\end{array}$ \\
\hline Red Ginseng & Anti-inflammation & Patients \\
\hline 6-Gingerol & $\begin{array}{l}\text { Anti-emetic activity by } \\
\text { inhibiting neurokinin-1, } \\
\text { serotonin, and } \\
\text { dopamine receptors }\end{array}$ & Patients \\
\hline Persumac & Unknown & Patients \\
\hline $\begin{array}{l}\text { Huang-Qin } \\
\text { decoction }\end{array}$ & $\begin{array}{l}\text { Regulation of glycine, } \\
\text { serine, and threonine } \\
\text { pathway as well as bile } \\
\text { acid metabolism } \\
\text { homeostasis }\end{array}$ & $\begin{array}{l}\text { Irinotecan-induced } \\
\text { gastrointestinal toxicity } \\
\text { and diarrhea in rats }\end{array}$ \\
\hline $\begin{array}{l}\text { Wei-Chang- } \\
\text { An } \\
\text { pill }\end{array}$ & $\begin{array}{l}\text { Anti-inflammation and } \\
\text { gastrointestinal } \\
\text { regulation }\end{array}$ & $\begin{array}{l}\text { 5-fluorouracil-induced } \\
\text { intestinal mucositis in } \\
\text { mice }\end{array}$ \\
\hline
\end{tabular}

$\begin{array}{lll}\text { Bu-Zhong-Yi- } & \text { Reducion of apoptosis } & \text { 5-fluorouracil-induced } \\ \text { Qi } & \text { and necrosis in } & \text { intestinal mucositis in } \\ \text { decoction } & \text { intestinal mucosal } & \\ & \text { epithelia via the } & \\ & \text { suppression of } & \\ & \text { inflammatory cytokine } & \\ & \text { upregulation }\end{array}$

\begin{tabular}{|c|c|}
\hline $\begin{array}{l}\text { Saireito } \\
(\mathrm{TJ}-114)\end{array}$ & $\begin{array}{l}\text { Inhibition of } \\
\text { cytokine-mediated } \\
\text { apoptosis in intestinal } \\
\text { crypt cells }\end{array}$ \\
\hline R. glutinosa & $\begin{array}{l}\text { Inhibition of oxidative } \\
\text { stress and inflammation }\end{array}$ \\
\hline $\begin{array}{l}18 \beta- \\
\text { Glycyrrhetinic } \\
\text { acid }\end{array}$ & $\begin{array}{l}\text { Inhibition of nuclear } \\
\text { NF-кB and caspases }\end{array}$ \\
\hline Rutin & $\begin{array}{l}\text { Anti-oxidation and } \\
\text { anti-inflammation }\end{array}$ \\
\hline N. sativa oil & Anti-oxidation \\
\hline
\end{tabular}

5-fluorouracil-induced intestinal mucositis in mice

Methotrexate-induced gut mucositis in rats

Cisplatin-induced oxidative intestinal damage in rats Methotrexate-induced intestinal lesion damage in rats Cisplatin-induced intestinal damage in rats

Cisplatin-induced intestinal injury in rats

\begin{tabular}{|c|c|c|}
\hline Thymoquinone & Anti-oxidation & $\begin{array}{l}\text { Cisplatin-induced } \\
\text { intestinal injury in rats }\end{array}$ \\
\hline
\end{tabular}

\section{Ingredients/Source}

Bacoside II, bacoside A3, bacosaponin C, and isomer of bacosaponin C

Ginsenosides

A major component of ginger

\section{R. Coriaria and B. Persicum}

Made from Glycyrrhiza uralensis, Paeonia lactiflora, Scutelleria baicalensis, and Ziziphus jujuba Main chemical constituents: baicalin, wogonoside, oroxylin-A-glucoside, baicalein, wogonin, orxylin-A, paeoniflorin, glycyrrhizic acid, glycyrrhetinic acid, liquiritin, isoliquirition, liquiritigenin, isoliquiritigenin, and ononin

Made from the extracts of Radix aucklandiae, Moschus, Lignum santali, Lignum aquilariae resinatum, Cinnabaris, Cortex magnoliae officinalis, Fructus aurantii, Radix et rhizoma rhei, Pulvis crotonis tiglium, Rhizoma chuanxiong, and Fructus jujubae

Main chemical constituents: costunolide, dehydrodehydrocostus lactone, naringin, hesperidin, neohesperidin, magnolol, honokiol, aloe-emodin, rhein, emodin, chrysophanol, and physcion

Made fromRadix Astragalus membranaeus, Radix Panax ginseng, Radix Angelica sinensis, Glycyrrhiza uralensis, Cimicifuga foetida Herba

Bupleurumchinense, Citrus sinensis Osbeck, and Atractylodes macrocephala

Main chemical constituents: astragalosides, acylsucrose derives,

dihydroxyflavone-glucopyranoside, liquiritin, liquiritin apioside, neolicuroside, hesperidin,

trihydrohyflavone-diglucopyranoside and cimicifugic acid $F$

A combined formulation of shosaikoto and goreisan containing saikosaponin, ginsenoside, glycyrrhizin, gingerol, and shogaol

Iridoid glycosides, phenethylalcohol glycosides and furfural derivatives

A pentacyclic triterpenoid derivative obtained from the herb liquorice

A flavone glycoside extensively found in black tea, apple skin peel and buckwheat

Rich in polyunsaturated fatty acids, such as omega-3 and omega- 6 fatty acids, phytosterols and several other substances including thymoquinone (up to $25 \%$ in volatile oil), carvacrol, t-anethole, sesquiterpenelongifolene, and 4 terpinol

A major principle active ingredient derived from $N$. sativa oil
References

Ullah et al., 2017

Kim H. S. et al., 2017

Konmun et al., 2017

Nazari et al., 2017

Cui et al., 2017;

Wang X. et al., 2017

Chen Y. et al., 2016

Gou et al., 2016

Kato et al., 2015

Shi et al., 2016

Rashid et al., 2017

Gautam et al., 2016

Shahid et al., 2017b

Shahid et al., 2017a 
TABLE 2 | Continued

\begin{tabular}{|c|c|c|c|c|}
\hline Name & Effect/Mechanism & $\begin{array}{l}\text { Experimental } \\
\text { setting/Model }\end{array}$ & Ingredients/Source & References \\
\hline $\begin{array}{l}\text { Zhu-Ye-Shi- } \\
\text { Gao } \\
\text { granule }\end{array}$ & $\begin{array}{l}\text { Inhibition of the release } \\
\text { of inflammatory } \\
\text { cytokines such as } \\
\mathrm{IL}-1 \beta, \mathrm{IL}-8 \text {, and tumor } \\
\text { necrosis factor- } \alpha\end{array}$ & $\begin{array}{l}\text { Patients with lung, } \\
\text { esophagus or } \\
\text { mediastinal cancer }\end{array}$ & $\begin{array}{l}\text { Made from Bamboo leaves, Gypsum fibrosuum, } \\
\text { Ginseng, Ophiopogon japonicas, Pinellia ternate, } \\
\text { Glycyrrhiza uralensis, and Oryza } \\
\text { Main chemical constituents: sativa Ginsenoside, } \\
\text { ruscogenin, succinic acid, and glycyrrhizic acid }\end{array}$ & $\begin{array}{l}\text { Wang L. J. et al., } \\
2017\end{array}$ \\
\hline A. vera & Anti-inflammation & Patients & $\begin{array}{l}\text { Acetylated mannans, polymannans, anthraquinone } \\
\text { C-glycosides, anthrones, emodin, and various } \\
\text { lectins }\end{array}$ & $\begin{array}{l}\text { Sahebnasagh et al., } \\
2017\end{array}$ \\
\hline Oroxylin & $\begin{array}{l}\text { Induction of } \mathrm{G} 2 / \mathrm{M} \\
\text { phase and activation of } \\
\text { cell apoptosis }\end{array}$ & TE13 and ECA109 cells & A natural flavonoid isolated from S. baicalensis & Tan et al., 2017 \\
\hline Proanthocyanidin & $\begin{array}{l}\text { Repair of damaged } \\
\text { DNA-dependent } \\
\text { activation of immune } \\
\text { sensitivity; amelioration } \\
\text { of mitochondrial } \\
\text { dysfunction }\end{array}$ & $\begin{array}{l}\text { Irradiation-treated } \\
\text { HFL1 cells }\end{array}$ & A class of polyphenols & $\begin{array}{l}\text { Katiyar et al., } 2017 \\
\text { Yang et al., } 2017\end{array}$ \\
\hline Green tea & $\begin{array}{l}\text { Anti-oxidation, } \\
\text { anti-bacterial, } \\
\text { anti-inflammation, and } \\
\text { anti-intestinal motility }\end{array}$ & $\begin{array}{l}\text { Patients with abdomen } \\
\text { and pelvic malignancy }\end{array}$ & Catechins & Emami et al., 2014 \\
\hline Silibinin & $\begin{array}{l}\text { Inhibition of DNA repair } \\
\text { signaling and } \\
\text { improvement of the } \\
\text { response to } \\
\text { radiotherapy }\end{array}$ & $\begin{array}{l}\text { Irradiation-treated } \\
\text { Human prostate } \\
\text { carcinoma DU145, } \\
\text { PC-3, and 22RV1 cells, } \\
\text { mouse keratinocyte } \\
\text { JB6 cells, human lung } \\
\text { cancer A549 cells, } \\
\text { murine non-invasive } \\
\text { MB49 and MB49-I cells }\end{array}$ & $\begin{array}{l}\text { A major active constituent of silymarin, a complex of } \\
\text { flavonolignans extracted from milk thistle }\end{array}$ & $\begin{array}{l}\text { Nambiar et al., 2015; } \\
\text { Prack Mc Cormick } \\
\text { et al., } 2018\end{array}$ \\
\hline Geraniin & $\begin{array}{l}\text { Suppression of DNA } \\
\text { damage }\end{array}$ & Irinotecan treated rats & A hydrolysable polyphenol from N. lappaceum & Bing et al., 2013 \\
\hline $\begin{array}{l}\text { C. } \\
\text { infortunatum }\end{array}$ & $\begin{array}{l}\text { Suppression of } \\
\text { Bax/Bcl-2 ratio and } \\
\text { COX-2 gene, } \\
\text { upregulation of DNA } \\
\text { repair gene ATM }\end{array}$ & $\begin{array}{l}\text { Mice exposed to } \\
\text { whole-body gamma } \\
\text { radiation }\end{array}$ & Flavonoids and saponins & Chacko et al., 2017 \\
\hline Fucoidan & $\begin{array}{l}\text { Upregulation of the } \\
\text { abundance of SCFA } \\
\text { producer } \\
\text { Coprococcus, } \\
\text { Rikenella, and } \\
\text { Butyricicoccus species } \\
\text { within the intestinal } \\
\text { mucosa }\end{array}$ & $\begin{array}{l}\text { Cyclophosphamide- } \\
\text { treated } \\
\text { mice }\end{array}$ & Fucose-containing sulfated polysaccharides & Shi et al., 2017 \\
\hline PHY906 & $\begin{array}{l}\text { Anti-inflammation and } \\
\text { anti-cancer }\end{array}$ & $\begin{array}{l}\text { CPT-11 treated } \\
\text { tumor-bearing mice }\end{array}$ & $\begin{array}{l}\text { Glycyrrhiza uralensis, Paeonia lactiflora, Scutelleria } \\
\text { baicalensis, and Ziziphus jujuba }\end{array}$ & Lam et al., 2014 \\
\hline Baicalin & $\begin{array}{l}\text { Down-regulation of } \\
\text { OATP2B1 }\end{array}$ & CPT-11 treated mice & A main constituent in PHY906 & Fujita et al., 2016 \\
\hline $\begin{array}{l}\text { Sheng-Jiang- } \\
\text { Xie-Xin } \\
\text { decoction }\end{array}$ & $\begin{array}{l}\text { Alteration of the activity } \\
\text { of CES2 and jejunal } \\
\text { UGT1A1 }\end{array}$ & Irinotecan treated rats & $\begin{array}{l}\text { Made from Pinellia ternata, Glycyrrhiza uralensis, } \\
\text { Coptis chinensis, Ziziphus jujuba, Zingiber officinale, } \\
\text { Scutellaria baicalensis, Codonopsis pilosula, and } \\
\text { Zingiber recens } \\
\text { Main chemical constituents: 6-gingerol, baicalin, } \\
\text { baicalein, wogonin, epiberberine, trigonelline, } \\
\text { liquiritin, lobetyolin, rutin, oleanolic acid, betulinic } \\
\text { acid, ursolic acid, berberine, and palmatine }\end{array}$ & Guan et al., 2017 \\
\hline
\end{tabular}


Of note, herbs are responsible for $24.2 \%$ of drug-induced liver injury cases ( $\mathrm{Li}$ et al., 2007). Systematic review shows that a comprehensive list of herbs can cause a high risk of hepatotoxicity in Korea (Lee et al., 2015). S. baicalensis is reported to induce autoimmune hepatitis in mice through modulating immune response (Wang et al., 2014). Thus, natural products-induced liver injury is a hot topic. In a recent case report, Turmeric interaction with paclitaxel induces an acute toxic hepatitis in Caucasian male with lung cancer probably by altering pharmacokinetic of paclitaxel in association with a contaminated Chlorella supplement (Costa et al., 2018). These observations indicate that some natural products may evoke acute hepatotoxicity possibly via the interaction with chemotherapeutic agents. Although the hepatotoxicity of some natural products remains speculative, the associated liver injury address the need to clarify and investigate the potential harmful effects. The natural products in this part together with relevant characteristics of the respective studies are summarized in Table 3.

\section{CAPACITY TO RELIEF NEPHROTOXICITY}

Nephrotoxicity is one of the most serious problem that hinders cisplatin-based chemotherapy (Mahmoodnia et al., 2017). In 2016, Shreesh Ojha et al. provide a review summarized plantderived natural products for counteracting cisplatin-induced nephrotoxicity (Ojha et al., 2016). Of note, oxidative stress is significantly related to cisplatin-induced nephrotoxicity in head and neck cancer patients (Quintanilha et al., 2018). Lycopene has anti-oxidative effect. The results from a doubleblind, randomized clinical trial show that lycopene is a useful adjuvant therapy, because its oral administration from 24 to $72 \mathrm{~h}$ after cisplatin administration can relief the complication of nephrotoxicity in cancer patients (Mahmoodnia et al., 2017). Hesperetin, a naturally-occurring bioflavonoid, protects against hydrogen peroxide-triggered oxidative damage via upregulation of Keap1-Nrf2/HO-1 pathway in ARPE-19 cells (Zhu et al., 2017). It normalizes renal function by attenuating cisplatininduced oxidative stress, lipid peroxidation, inflammatory cytokine, and histopathological alteration in rats (Budhani et al., 2014). Fruits of Withania coagulans contain several bioactive compounds as curative agents for various clinical conditions. This fruit extract prevents against cisplatin-induced kidney damage, primarily through its free radical scavenging and anti-inflammatory activity (Sharma et al., 2017). Pine bark extract with potent anti-oxidant activity attenuates cisplatininduced kidney injury of rats (Lee et al., 2017). Silybin (a main flavonoid of $S$. marianum) as a pharmacological activator of SIRT3, has capable of protection against cisplatin-induced tubular cell apoptosis and acute kidney injury by improving mitochondrial function (Li et al., 2017). Origanum majorana is commonly known as marjoram in traditional medicine, which possesses anti-oxidant, anti-microbial and anti-inflammatory activities (Leyva-Lopez et al., 2017). Its anti-proliferative effect is observed in human hepatocarcinoma cells (Fathy et al., 2016). Moreover, O. majorana and its polyphenol carnosol have anti-metastatic and antitumor effects in breast cancer cells (Al Dhaheri et al., 2013, 2014). Its ethanol extract significantly reduces cisplatin-induced nephrotoxicity in rats, possibly through enhancing free radical scavenging activity (Soliman et al., 2016).

Other chemotherapy agents such as adriamycin, 5fluorouracil, methotrexate, ifosfamide and doxorubicin also cause nephrotoxicity. Traditional Chinese medicine Qi-LuXiao-Bai decoction can inhibit connective tissue growth factor, fibronectin and $\alpha$-smooth muscle actin expression, and improve glomerular sclerosis in adriamycin-induced nephropathy in rats (Su et al., 2015). Multi-glycoside of Tripterygium wilfordii, a Chinese herbal medicine, is clinically effective in improving glomerulosclerosis in chronic kidney disease. It effectively and safely relieves the prolonged glomerulosclerosis in adriamycin-induced nephropathy in rats, possibly via the reduction of extracellular matrix components and suppression of TGF- $\beta 1 /$ Smad signaling (Wan et al., 2014). N. sativa and its constituent thymoquinone have potential renoprotective effect on chemotherapy-associated kidney complication, possibly via decreasing lipid peroxidation and increasing anti-oxidant enzyme activity (Cascella et al., 2017). Traditional herbal medicine Thymus vulgaris has anti-oxidant property (Heidari et al., 2018). Its anticancer effect is observed in human leukemia THP-1 cells and colorectal cancer cells (Ayesh et al., 2014; Al-Menhali et al., 2015). Naringenin, a natural flavanone isolated from $T$. vulgaris, has growth inhibitory and chemosensitization effects on human breast and colorectal cancer (Abaza et al., 2015). Naringenin can ameliorate daunorubicininduced nephrotoxicity in rats by mitigating inflammation (Karuppagounder et al., 2015).

Kidney is a radiosensitive organ. Acorus calamus is a wellknown plant in Asia traditional medicine for centuries. Its extract significantly increases major enzyme activity of the antioxidant defense system and decreases DNA strand breaks in liver and kidney of irradiated mice (Sandeep and Nair, 2012). The dried fruit of Xylopia aethiopica is used in folk medicines and widely consumed as a spice in Nigeria, with anti-plasmodial, anti-oxidant, hypotensive and diuretic effects (Tatsadjieu et al., 2003; Karioti et al., 2004). It increases the antioxidant defense system in liver and kidney of irradiated rats (Adaramoye et al., 2011). Quercetin also attenuates irradiationinduced kidney injury via its anti-oxidant activity (Ozyurt et al., 2014). Genistein, found in soybean products, has anti-oxidant and anti-inflammatory properties with low toxicity. Genistein is suggested be a chemotherapeutic agent against different types of cancer, mainly by changing apoptosis, cell cycle and angiogenesis and inhibiting metastasis (Spagnuolo et al., 2015). Melatonin is a potent free radical scavenger with anti-inflammation. The supplementation of genistein and melatonin prior to irradiation protects against nephrotoxicity in mice (Canyilmaz et al., 2016).

Nutritional supplement ingredients have attracted the attention for the ability to prevent and treat kidney injury. Honey and royal jelly are effective in reducing cisplatin-induced acute kidney injury in cancer patients (Osama et al., 2017). Ginger extract shows renoprotective effects on radiotherapy-induced renal histological and biochemical alteration in rats (Saberi 
TABLE 3 | Natural products in reducing chemotherapy and radiotherapy-induced hepatotoxicity.

\begin{tabular}{|c|c|c|c|c|}
\hline Name & Effect/Mechanism & $\begin{array}{l}\text { Experimental } \\
\text { setting/Model }\end{array}$ & Ingredients/Source & References \\
\hline Ashwagandha & Anti-oxidant & $\begin{array}{l}\text { Radiation-induced } \\
\text { hepatotoxicity in rats }\end{array}$ & Alkaloids, withanolides, and several sitoindosides & $\begin{array}{l}\text { Hosny Mansour and } \\
\text { Farouk Hafez, } 2012\end{array}$ \\
\hline N. sativa oil & $\begin{array}{l}\text { Reduction of oxidative } \\
\text { stress, inflammatory, } \\
\text { and fibrogenic markers }\end{array}$ & $\begin{array}{l}\text { Irradiation-induced liver } \\
\text { injury in rats }\end{array}$ & $\begin{array}{l}\text { Rich in polyunsaturated fatty acids, such as } \\
\text { omega- } 3 \text { and omega- } 6 \text { fatty acids, phytosterols, } \\
\text { and several other substances including } \\
\text { thymoquinone (up to } 25 \% \text { in volatile oil), carvacrol, } \\
\text { t-anethole, sesquiterpenelongifolene and } 4 \text { terpinol }\end{array}$ & $\begin{array}{l}\text { Radwan and } \\
\text { Mohamed, } 2018\end{array}$ \\
\hline Milk thistle & $\begin{array}{l}\text { Anti-oxidation, } \\
\text { Anti-inflammation, and } \\
\text { anti-fibrosis }\end{array}$ & Patients & Silymarin & $\begin{array}{l}\text { Frassova and } \\
\text { Ruda-Kucerova, } 2017\end{array}$ \\
\hline $\begin{array}{l}\text { Active } \\
\text { Hexose } \\
\text { Correlated } \\
\text { Compound }\end{array}$ & $\begin{array}{l}\text { Anti-oxidantion, } \\
\text { anti-inflammation, } \\
\text { anti-tumor effect, } \\
\text { anti-infectious effect } \\
\text { and immunoenhancing } \\
\text { activity }\end{array}$ & Patients & $\begin{array}{l}\text { A culture extract of mycelium of Lentinula edodes } \\
\text { (Basiomycetes family of fungi) }\end{array}$ & Ito et al., 2014 \\
\hline $\begin{array}{l}\text { Pine bark } \\
\text { extract }\end{array}$ & Anti-oxidation & $\begin{array}{l}\text { Cisplatin-induced } \\
\text { hepatotoxicity and oxidative } \\
\text { stress in rats }\end{array}$ & Mixture of bioflavonoids & Ko et al., 2014 \\
\hline Pomegranate & Anti-oxidation & $\begin{array}{l}\text { Cisplatin-induced liver } \\
\text { damage in rabbits }\end{array}$ & Robust polyphenolic flavonoid & Yildirim et al., 2013 \\
\hline$P$. fraternus & $\begin{array}{l}\text { Reduction of } \\
\text { mitochondrial damage }\end{array}$ & $\begin{array}{l}\text { Cisplatin and } \\
\text { cyclophosphamide-induced } \\
\text { hepatotoxicity and } \\
\text { nephrotoxicity in rats }\end{array}$ & Alkaloids, flavonoids, lignans, phenols, and terpenes & Kumari and Setty, 2012 \\
\hline $\begin{array}{l}\text { Grape seed } \\
\text { extract }\end{array}$ & $\begin{array}{l}\text { Reduction of oxidative } \\
\text { stress, hyperlipidemia } \\
\text { and hematological } \\
\text { alterations }\end{array}$ & $\begin{array}{l}\text { Dexamethasone-induced } \\
\text { liver histopathological } \\
\text { change in rats }\end{array}$ & $\begin{array}{l}\text { A number of polyphenols, including procyanidins } \\
\text { and proanthocyanidins }\end{array}$ & $\begin{array}{l}\text { Hasona and Morsi, } \\
2018\end{array}$ \\
\hline $\begin{array}{l}\text { Ginsenoside } \\
\text { Rg1 }\end{array}$ & $\begin{array}{l}\text { Regulation of Nrf2 } \\
\text { signaling pathway }\end{array}$ & $\begin{array}{l}\text { Cisplatin-induced } \\
\text { hepatotoxicity in mice }\end{array}$ & A main compound of Ginseng & Gao et al., 2017 \\
\hline Turmeric & $\begin{array}{l}\text { Induction of an acute } \\
\text { toxic hepatitis by } \\
\text { interacting with } \\
\text { paclitaxel }\end{array}$ & Patients & $\begin{array}{l}\text { An herbaceous perennial plant originated from } \\
\text { Southeast Asia }\end{array}$ & Costa et al., 2018 \\
\hline S. baicalensis & $\begin{array}{l}\text { Induction of } \\
\text { autoimmune hepatitis }\end{array}$ & Mice & A principal constituents of Shosaikoto (or TJ-9) & Wang et al., 2014 \\
\hline
\end{tabular}

et al., 2017). Purslane (Portulaca oleracea), widely distributed around the globe in traditional medicine, significantly attenuates lipid alteration, liver, and kidney function as well as oxidative stress in irradiated rats (Abd El-Azime et al., 2014). American ginseng berry extract also has nephroprotective effect against cisplatin-evoked nephrotoxicity in mice through ROS-mediated mitogen activated protein kinase (MAPK) and NF- $\kappa$ B signaling pathway (Ma et al., 2017). Curcumin and its analog difluorinated curcumin potentially reduce cisplatin-induced nephrotoxicity, thereby enhance the therapeutic window of cisplatin, the latter also decreases inflammatory factors NF- $\mathrm{B}$ and COX-2, oxidative stress as well as multi-drug resistance markers (Sahin et al., 2014; Ugur et al., 2015). A Se-polysaccharide from Se-enriched G. frondosa (Se-GFP-22) significantly enhances the anti-oxidant and immunomodulatory activities in kidney of cyclophosphamide-treated mice ( $\mathrm{Li}$ et al., 2018). Grape seed extract is found to reduce severe acute tubular necrosis and improve kidney function in cisplatin-treated rabbits, partially showing its protective effect against nephrotoxicity (Benzer et al., 2012). Recently, grape seed proanthocyanidin extract reduces thalidomide and carboplatin combinationinduced renal damage in rats by reducing oxidative stress, inflammation, p53 change, and apoptosis (Yousef et al., 2018), as well as attenuates arsenic-induced renal inflammatory injury in mice by inhibiting NF- $\mathrm{B}$ signaling activation and inflammatory cytokine production (Wang C. et al., 2017). Up to $2,500 \mathrm{mg}$ of this extract administration for 4 weeks is found to be generally safe and well-tolerated in humans (Sano, 2017). These observations may offer a promising chance for clinically meaningful prevention of chemotherapy and radiotherapy-induced nephrotoxicity by natural products. The natural products in this part together with relevant characteristics of the respective studies are summarized in Table 4. 
TABLE 4 | Natural products in reducing chemotherapy and radiotherapy-induced nephrotoxicity.

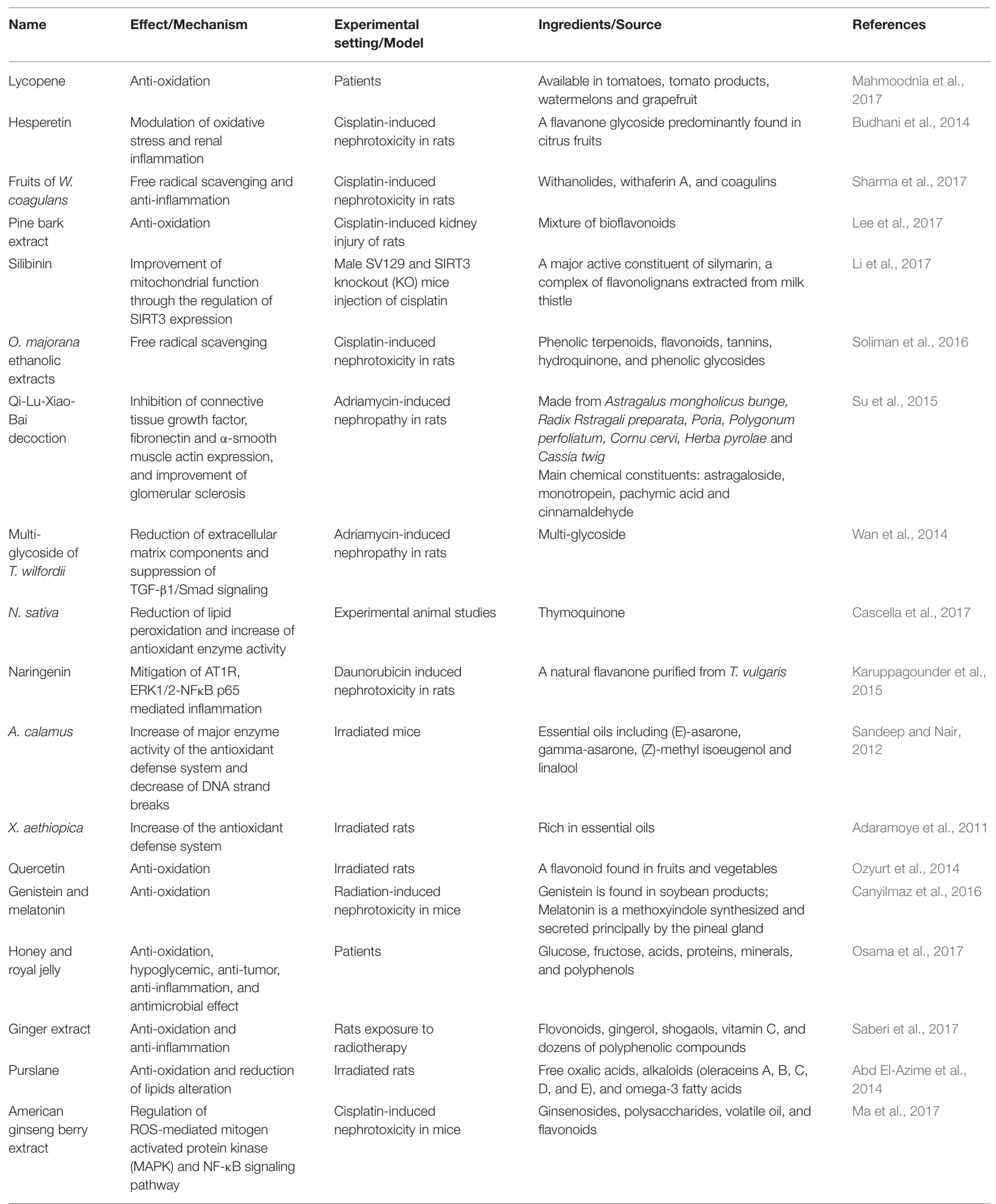




\begin{tabular}{|c|c|c|c|c|}
\hline Name & Effect/Mechanism & $\begin{array}{l}\text { Experimental } \\
\text { setting/Model }\end{array}$ & Ingredients/Source & References \\
\hline Curcumin & $\begin{array}{l}\text { Increase of the NAMPT and } \\
\text { SIRT protein levels }\end{array}$ & Cisplatin-treated rats & Bioactive constituent of Curcuma longa L. & Ugur et al., 2015 \\
\hline $\begin{array}{l}\text { Difluorinated } \\
\text { curcumin }\end{array}$ & $\begin{array}{l}\text { Reduction of inflammatory } \\
\text { factors NF- } \mathrm{B} \text { and COX-2, } \\
\text { oxidative stress as well as } \\
\text { multi-drug resistance } \\
\text { markers organic cation } \\
\text { transporters }\end{array}$ & $\begin{array}{l}\text { Cisplatin-induced } \\
\text { nephrotoxicity in rats }\end{array}$ & Curcumin analog & Sahin et al., 2014 \\
\hline $\begin{array}{l}\text { Se-enriched } \\
\text { G. frondosa } \\
\text { (Se-GFP-22) }\end{array}$ & Anti-oxidation & $\begin{array}{l}\text { Cyclophosphamide-treated } \\
\text { mice }\end{array}$ & Se-polysaccharide & Li et al., 2018 \\
\hline $\begin{array}{l}\text { Grape seed } \\
\text { proanthocyanidin } \\
\text { extract }\end{array}$ & $\begin{array}{l}\text { Reduction of renal damage, } \\
\text { oxidative stress, } \\
\text { inflammation, tumor } \\
\text { suppressor protein p53 } \\
\text { change, as well as renal cell } \\
\text { apoptosis; inhibition of } \\
\text { NF-кB signaling pathway } \\
\text { and inflammatory cytokine } \\
\text { production }\end{array}$ & $\begin{array}{l}\text { Thalidomide and } \\
\text { carboplatin-treated rats }\end{array}$ & Proanthocyanidin & $\begin{array}{l}\text { Sano, 2017; Wang C. } \\
\text { et al., 2017; Yousef } \\
\text { et al., } 2018\end{array}$ \\
\hline
\end{tabular}

\section{IMPROVEMENT OF HEMATOPOIETIC SYSTEM INJURY, PARTICULARLY IMPORTANT FOR BONE MARROW HEMATOPOIETIC MICROENVIRONMENT}

Myelosuppression with leukocytopenia, erythrocytopenia, and thrombocytopenia, are serious and common side effects during cancer treatment. A systematic review and meta-analysis of randomized controlled trials show that Chinese herbal medicine as an adjuvant can alleviate chemotherapy or radiotherapyinduced myelosuppression, and maintain therapeutic dose and treatment cycle by reducing grade III-IV toxicity, (Hou et al., 2017). A Chinese herbal medicine Shuang-Huang-Sheng-Bai granule approved by the Food and Drug Administration of China, can effectively treat cancer. Recently, this granule is observed to elevate white blood cell count, and reduce the incidence of chemotherapy-caused myelosuppression in cancer patients compared with control group taken with Leucogon tablet, demonstrating its protection against bone marrow suppression and alleviation of clinical symptoms (Wang L. F. et al., 2017).

Cyclophosphamide is of great interest in the clinic due to its relatively high oncotoxic specificity. Sheng-Mai injection is derived from Sheng-Mai-San, a well-known traditional Chinese herbal prescription. This injection has therapeutic potential in reducing chemotherapy-induced adverse effects and improving life quality in patients with non-small cell lung cancer. Recently, a meta-analysis shows that combination of Sheng-Mai injection with chemotherapy significantly reduces grade 3/4 myelosuppression compared with the chemotherapy alone in cancer patients (Duan et al., 2018). Chinese Ginseng is well-known to strengthen the body resistance to eliminate pathogenic factors, and reduce side effects of chemotherapy drugs. Panaxadiol saponins, a biologically active fraction derived from Ginseng, possess hematopoietic growth factor-like activity that promotes proliferation and differentiation of HPCs in cyclophosphamide-induced myelosuppressive mice, probably by regulating MAPK/ERK kinase (MEK) and extracellular signalregulated kinase (ERK) protein kinases, C-kit, and GATA-1 transcription factors (Sun X. et al., 2018). Ginsenoside Rg3 is used as a potent anticancer agent to induce apoptosis, inhibit proliferation, metastasis and angiogenesis, as well as promote immunity during conventional cancer therapy (Sun et al., 2017). A multicenter, large-sample, randomized clinical trial shows that ginsenoside Rg3 improves the median survival time and reduces myelosuppression in advanced nonsmall cell lung cancer patients during the standard firstline chemotherapy (Zhang et al., 2018). Dang-Gui-Bu-Xue decoction, a classical formula of traditional Chinese medicine, has an impact on promoting hematopoiesis, and prevents myelosuppression in breast cancer patients treated with adjuvant chemotherapy. However, a phase II randomized prospective controlled clinical study is conducted from December 2013 to February 2015, and shows that this decoction fails to prevent myelosuppression in breast cancer patients treated with adjuvant chemotherapy (Hong et al., 2017). Further studies are warranted to validate the efficacy of Dang-Gui-Bu-Xue decoction in selected patients.

Infection and inflammation are observed in chemotherapy and radiotherapy patients with myelosuppression. A traditional medicinal formula Dang-Gui-Si-Ni decoction has been clinically used for infectious diseases that are complicated with hemodynamic instability (Yao et al., 2014). This decoction significantly elevates the level of bone marrow hematopoietic stem progenitor cells in myelosuppression model of mice (Chen et al., 2015). Herba Epimedii, one of most popular 
Chinese herbs, is used for the treatment of osteoporosis and inflammation. H. Epimedii and its main constituent icariin can improve immune function after cyclophosphamideinduced myelosuppression (Zhao et al., 2010). Icaritin, hydrolyzed by icariin, prevents cyclophosphamide-induced myelosuppression in mice by improving bone marrow hematopoietic microenvironment, promoting the proliferation and differentiation of HSCs, inhibiting the apoptosis of HSCs and stimulating granulocyte colony-stimulating factor and thyroperoxidase (Sun C. et al., 2018). A herbal medicine Radix Sanguisorbae used to treat diarrhea, enteritis, duodenal ulcers, and internal hemorrhage, is clinically effective against myelosuppression induced by chemotherapy and/or radiotherapy (Seo et al., 2016). Its main ingredients saponins show hematopoietic effect mediated by focal adhesion kinase (FAK) and ERK1/2 activation as well as cytokine inhibition in the bone marrow (Chen X. et al., 2017). Paeoniflorin and albiflorin, two active constituents identified from the root of $P$. lactiflora, can increase the white blood cell counts, reverse the atrophy of thymus, and suppress cyclophosphamide and radiotherapy-induced myelosuppression in animals, showing hematopoietic effect (Zhu Y. et al., 2016; Zhu Y.-L. et al., 2016).

Anti-oxidant natural products can prevent excessive ROS produced by chemotherapy and radiotherapy from killing white blood cells and inhibiting bone marrow suppression. Chinese medicine Yi-Qi-Yang-Yin formula can ameliorate hematopoietic system injury by reducing intracellular ROS levels in hematopoietic cells of mice after total body irradiation (Zhang et al., 2017). San-Yang-Xue-Dai mixture is a natural medicine originating from an ancient prescription of the Dai nationality in Southwest China. It attenuates doxorubicininduced myelosuppression by inhibiting ROS-mediated apoptosis (Chen T. et al., 2017). Coriander (Coriandrum sativum) is an annual herb used as a flavoring agent and traditional remedy. Its extract can scavenge ROS and upregulate endogenous cellular antioxidant system (Velaga et al., 2014; Zielniok et al., 2016). Recently, rutin-enriched coriander extract is found to ameliorate ionizing radiation-induced myelosuppression with improvement of the proliferation and differentiation ability of hematopoietic stem and progenitor cells in mice, probably by inhibiting apoptosis and DNA damage attributed to its scavenging ROS and activating antioxidant enzyme ability (Han et al., 2017a). Theaflavin, one of the tea pigments from black tea, prevents the progression of inflammatory disorder, cancer, bacterial and viral infection, and ameliorates ionizing radiation-induced HSC injury in mice by regulating Nrf2 pathway to reduce oxidative stress (Han et al., 2017b). Astaxanthin, predominantly found in marine organisms, can improve radiation-induced skewed differentiation of peripheral blood cells and accelerate hematopoietic selfrenewal and regeneration in mice. This radio-protective effect is probably mediated by scavenging of ROS, activation of Nrf2 and downstream anti-oxidative proteins (Xue et al., 2017). The natural products in this part together with relevant characteristics of the respective studies are summarized in Table 5 .

\section{ATTENUATION OF CARDIOTOXICITY MAINLY BY BALANCING ENERGY METABOLISM AND ANTIOXIDANT SYSTEM}

Energy metabolism imbalance and oxidative stress mediate chemotherapeutic agents-induced cardiotoxicity. Doxorubicin has cumulative and dose-related cardiotoxicity. In 2017, Sahebkar et al. review the attenuation of doxorubicin-induced cardiotoxicity by plant extracts and phytochemicals (Hosseini and Sahebkar, 2017). In 2018, Yu et al. also review the protective effects of natural products on doxorubicin-caused cardiotoxicity without affecting its anticancer efficacy ( $\mathrm{Yu}$ et al., 2018b). A Chinese medicine Dan-Hong injection is demonstrated to alleviate ischemic myocardial injury and improve heart function. Recently, this injection is reported to restore doxorubicin-induced cardiotoxicity in $\mathrm{H} 9 \mathrm{c} 2$ cells by improving energy metabolism and reducing oxidative stress (Yi et al., 2018). San-Yang-Xue-Dai mixture alleviates doxorubicininduced cardiotoxicity and apoptosis by inhibiting p53 and MAPK signaling activation (Chen et al., 2018). Fermented Cordyceps sinensis is reported to attenuate doxorubicininduced cardiotoxicity by inhibiting myocardial hypertrophy and myocardial damage, regulating systolic function, and antioxidant enzyme system and improving cardiac energy metabolism (Wu et al., 2018). Chinese herb Salvia miltiorrhiza is used as an empiric treatment for cardiovascular disorders (Zhou et al., 2012). Its main compound diethyl blechnic inhibits doxorubicin-induced apoptosis by inhibiting ROS in $\mathrm{H} 9 \mathrm{c} 2$ cells and primary rat cardiomyocytes ( $\mathrm{Yu}$ et al., 2018a). Curcumin also protects the myocardium against doxorubicin-induced cardiotoxicity in mouse hearts and primary cardiomyocytes, probably via upregulating 14-3$3 \gamma$ expression (He et al., 2018). Natural steroid saponin dioscin found abundantly in legumes and yams, alleviates doxorubicin-induced cardiotoxicity by regulating miR140-5p-mediated myocardial oxidative stress (Zhao et al., 2018).

Anthracycline also causes cardiotoxicity in cancer patients. Modified Zhi-Gan-Cao-Tang relieves anthracycline-induced congestive heart failure in an 18-year-old adolescent male ( $\mathrm{Wu}$ et al., 2015). Platycodon grandiflorum is used in traditional Chinese medicine for centuries to treat cardiovascular disease. It can nourish $Q i$ and relieve symptoms such as palpitations, shortness of breath, and chest pain. A randomized controlled trial reveals that $P$. grandiflorum has cardioprotective effect in early breast cancer patients undergoing anthracycline-based chemotherapy (Hao et al., 2017). Flaxseed oil (containing $\alpha$-linolenic acid) reduces arsenic-induced cardiac toxicity in rats (Varghese et al., 2017). Parsley oil with anti-oxidant, anti-inflammatory and anti-apoptotic actions is reported to ameliorate cisplatin-induced hepatic and cardiac injury in rats (Abdellatief et al., 2017). Blueberry anthocyanins-enriched extract with anti-inflammatory and anti-oxidant activities attenuates cyclophosphamide-induced cardiotoxicity of rats (Liu et al., 2015). Rubia cordifolia is a valuable medicinal herb in 
TABLE 5 | Natural products in reducing chemotherapy and radiotherapy-induced hematopoietic system injury.

\begin{tabular}{|c|c|c|c|c|}
\hline Name & Effect/Mechanism & $\begin{array}{l}\text { Experimental } \\
\text { setting/Model }\end{array}$ & Ingredients/Source & References \\
\hline $\begin{array}{l}\text { Shuang-Huang- } \\
\text { Sheng-Bai } \\
\text { granule }\end{array}$ & $\begin{array}{l}\text { Elevation of white blood cells, } \\
\text { promotion of the proliferation and } \\
\text { differentiation of hematopoietic } \\
\text { stem/progenitor cells, and the } \\
\text { growth of bone marrow } \\
\text { hematopoietic cells, inhibition of } \\
\text { tumor cell growth and some } \\
\text { immunomodulatory effects }\end{array}$ & Patients & $\begin{array}{l}\text { Made from Astragalus membranaceus, Rhizoma } \\
\text { polygonati, Rhizoma drynariae, Fructus ligustri } \\
\text { lucidi, Radix trichosanthes, and Herba epimedii } \\
\text { Main chemical constituents: astragaloside, } \\
\text { polysaccharides, naringin, specnuezhenide, and } \\
\text { icariin }\end{array}$ & $\begin{array}{l}\text { Wang L. F. et al., } \\
2017\end{array}$ \\
\hline $\begin{array}{l}\text { Sheng-Mai } \\
\text { injection }\end{array}$ & $\begin{array}{l}\text { Improvement in quality of life, } \\
\text { increase of the cellular immunity }\end{array}$ & Patients & $\begin{array}{l}\text { Made from Radix ginseng, Radix ophiopogonis, and } \\
\text { Fructus schisandrae chinensis } \\
\text { Main chemical constituents: ginsenoside Rg1, } \\
\text { ginsenoside Re, ginsenoside Rb1, ophiopogonin D, } \\
\text { ophiopogonin D', ophiogonanone A and } \\
\text { ophiogonanone B }\end{array}$ & Duan et al., 2018 \\
\hline $\begin{array}{l}\text { Panaxadiol } \\
\text { saponins }\end{array}$ & $\begin{array}{l}\text { Regulation of MEK and ERK } \\
\text { protein kinases, C-kit, and } \\
\text { GATA-1 transcription factors }\end{array}$ & $\begin{array}{l}\text { Cyclophosphamide- treated } \\
\text { mice }\end{array}$ & Derived from Ginseng & Sun X. et al., 2018 \\
\hline Ginsenoside Rg3 & $\begin{array}{l}\text { Induction of apoptosis, inhibition } \\
\text { of proliferation, metastasis, and } \\
\text { angiogenesis, promotion of } \\
\text { immunity }\end{array}$ & Patients & A main compound of Ginseng & Zhang et al., 2018 \\
\hline $\begin{array}{l}\text { Dang-Gui-Bu-Xue } \\
\text { decoction }\end{array}$ & $\begin{array}{l}\text { No prevention of } \\
\text { myelosuppression in breast } \\
\text { cancer patients }\end{array}$ & Patients & $\begin{array}{l}\text { Made from Radix astragali and Radix Angelicae } \\
\text { sinensis } \\
\text { Main chemical constituents: calycosin-7-glucoside, } \\
\text { ononin, calycosin, formononetin, Z-ligustilide, } \\
\text { astragaloside IV, astragaloside II and astragaloside I }\end{array}$ & Hong et al., 2017 \\
\hline $\begin{array}{l}\text { Dang-Gui-Si-Ni } \\
\text { decoction }\end{array}$ & $\begin{array}{l}\text { Upregulation of thrombopoietin } \\
\text { expression }\end{array}$ & $\begin{array}{l}\text { Myelosuppression model of } \\
\text { mice }\end{array}$ & $\begin{array}{l}\text { Made from Angelica sinensis, Cinnamomi cassia, } \\
\text { Paeonia lactiiflora, Tetrapanax papyriferus, Asarum } \\
\text { heterotropoides, Glycyrrhiza uralensis and Ziziphus } \\
\text { jujuba } \\
\text { Main chemical constituents: ferulic acid, } \\
\text { paeoniflorin, cinnamic acid, and glycyrrhizic acid }\end{array}$ & Chen et al., 2015 \\
\hline Icaritin & $\begin{array}{l}\text { Promoting the proliferation and } \\
\text { differentiation of hematopoietic } \\
\text { stem cells, inhibition of apoptosis } \\
\text { and stimulating the expression of } \\
\text { granulocyte colony-stimulating } \\
\text { factor and thyroperoxidase }\end{array}$ & $\begin{array}{l}\text { Cyclophosphamide-induced } \\
\text { myelosuppression in mice }\end{array}$ & Hydrolyzed by icariin & Sun C. et al., 2018 \\
\hline Saponins & $\begin{array}{l}\text { Activation of focal adhesion } \\
\text { kinase (FAK) and Erk } 1 / 2 \text {, } \\
\text { inhibition of the cytokine } \\
\text { expression }\end{array}$ & Myelosuppressive mice & A main ingredients of Radix Sanguisorbae & $\begin{array}{l}\text { Chen X. et al., } \\
2017\end{array}$ \\
\hline $\begin{array}{l}\text { Paeoniflorin and } \\
\text { albiflorin }\end{array}$ & $\begin{array}{l}\text { Increase of the white blood cell } \\
\text { counts, attenuation of the } \\
\text { atrophy of thymus }\end{array}$ & $\begin{array}{l}\text { Cyclophosphamide and } \\
\text { radiotherapy-induced } \\
\text { myelosuppression in } \\
\text { animals }\end{array}$ & $\begin{array}{l}\text { Active constituents derived from the root of } P \text {. } \\
\text { lactiflora }\end{array}$ & $\begin{array}{l}\text { Zhu Y. et al., 2016; } \\
\text { Zhu Y.-L. et al., } \\
2016\end{array}$ \\
\hline $\begin{array}{l}\text { Yi-Qi-Yang-Yin } \\
\text { formula }\end{array}$ & Anti-oxidation & $\begin{array}{l}\text { Mice after total body } \\
\text { irradiation }\end{array}$ & $\begin{array}{l}\text { Made from Astragalus root, Ginseng, glossy privet } \\
\text { fruit, Eclipta alba, Chinese Angelica, Bighead } \\
\text { Atractylodes rhizome, Wolfiporia extensa, and Radix } \\
\text { Glycyrrhizae Preparata } \\
\text { Main chemical constituents: astragaloside, } \\
\text { ginsenoside, specnuezhenide, ferulic acid, and } \\
\text { glycyrrhizic acid }\end{array}$ & Zhang et al., 2017 \\
\hline $\begin{array}{l}\text { San-Yang-Xue-Dai } \\
\text { mixture }\end{array}$ & $\begin{array}{l}\text { Inhibition of ROS-mediated } \\
\text { apoptosis }\end{array}$ & Doxorubicin-treated mice & $\begin{array}{l}\text { Made from Sanguis draconis, Radix et Rhizoma } \\
\text { Notoginseng, Radix et Rhizoma Glycyrrhizae and } \\
\text { Radix Angelicae Sinensis } \\
\text { Main chemical constituents: bornyl acetate, } \\
\text { dracorhodin, ferulic acid, glycyrrhizic acid, } \\
\text { 6-gingerol, ginsenoside Rg1, ginsenoside Rb1 and } \\
\text { notoginsenoside R1 }\end{array}$ & $\begin{array}{l}\text { Chen T. et al., } \\
2017\end{array}$ \\
\hline
\end{tabular}


TABLE 5 | Continued

\begin{tabular}{|c|c|c|c|c|}
\hline Name & Effect/Mechanism & $\begin{array}{l}\text { Experimental } \\
\text { setting/Model }\end{array}$ & Ingredients/Source & References \\
\hline $\begin{array}{l}\text { Rutin-enriched } \\
\text { coriander extract }\end{array}$ & $\begin{array}{l}\text { Inhibition of ROS-mediated } \\
\text { apoptosis and DNA damage }\end{array}$ & $\begin{array}{l}\text { lonizing radiation-induced } \\
\text { hematopoietic injury of mice }\end{array}$ & $\begin{array}{l}\text { Phenolic acids (caffeic acid, protocatechinic acid, } \\
\text { and gentisic acid), glycitin, and pyrogallol }\end{array}$ & Han et al., 2017a \\
\hline Theaflavin & $\begin{array}{l}\text { Anti-oxidation via the Nrf2 } \\
\text { pathway }\end{array}$ & $\begin{array}{l}\text { lonizing radiation-induced } \\
\text { HSC injury in mice }\end{array}$ & Tea pigments from black tea & Han et al., 2017b \\
\hline Astaxanthin & $\begin{array}{l}\text { Anti-oxidation, activation of Nrf2 } \\
\text { and anti-oxidative proteins }\end{array}$ & Radiation-induced mice & Found in marine organisms & Xue et al., 2017 \\
\hline
\end{tabular}

the Ayurvedic system. Its extract can protect cyclophosphamideinduced cardiac tissue injury of rats by modulating anti-oxidant markers (Chandrashekar et al., 2018).

Radiotherapy-driven heart injury remains a major issue for cancer survivors. A traditional Chinese medicine ShengMai-San is used to improve the syndrome of $Q i$ and Yin deficiency, and has the ability to treat patients with cardiac diseases, fatigue and cancer. It also enhances heart function and improves the quality of life in cancer patients undergoing chemotherapy or radiotherapy (Lo et al., 2012). Black grape juice protects against whole body $\gamma$-irradiation-induced heart toxicity of rats with the alteration of metabolites from lipid peroxidation and lactate dehydrogenase (de Freitas et al., 2013). A natural polyphenol zingerone due to its anti-oxidative and anti-inflammatory properties can prevent against cisplatin- or $\gamma$-radiation-induced cardiotoxicity in rats by decreasing caspase3 expression and the prominent nuclear DNA fragmentation as well as increasing mitochondrial complexes' activities (Soliman et al., 2018). A citrus flavanoglycone hesperidin also restores whole body $\gamma$-irradiation-induced cardiocellular damage and oxidative stress in rats (Pradeep et al., 2012). These observations suggest that natural products may be the effective agents used as an adjunct/dietary supplement for the cancer patients receiving chemotherapy and radiotherapy. The natural products in this part together with relevant characteristics of the respective studies are summarized in Table 6.

\section{NEED TO CLARIFY THE PREVENTION OF NEUROTOXICITY}

Neurotoxicity is a frequent adverse effect of cancer chemotherapy and radiotherapy, and causes excruciating pain to cancer patients. A network meta-analysis shows that Ai-Di, ShenQi-Fu-Zheng, and Matrine injections approved by the Food and Drug Administration of China, improve the overall response rate and quality of life, and reduce the incidence of peripheral neurotoxicity (III-IV) for advanced colorectal cancer treated with oxaliplatin, 5-fluorouracil, and leucovorin (Ge et al., 2016). Traditional Japanese medicine Goshajinkigan (TJ107) is used to alleviate neuropathy and general pain. Shakuyakukanzoto (TJ68) effectively treats muscle cramps and crampy pain. A multicenter retrospective study shows that TJ107 and TJ68 reduce neurotoxicity without negatively affecting tumor response in patients with colorectal cancer who undergo 5-fluorouracil/folinic acid plus oxaliplatin therapy (Hosokawa et al., 2012). A systematic review and meta-analysis shows that Radix Astragali intervention may be beneficial in reducing oxaliplatin-induced peripheral neuropathy (Deng et al., 2016a). Recently, its hydroalcoholic extract (containing astragalosides) is reported to relieve pain and promote the rescue mechanisms for the protection of nervous tissue in oxaliplatininduced neuropathy of rats (Mannelli et al., 2017) as well as prevents against oxaliplatin-induced lipid peroxidation and DNA oxidation in astrocytes (Mannelli et al., 2015), further demonstrating the anti-neuropathic profile of Radix Astragali.

Currently, chemotherapy and radiotherapy-induced peripheral neuropathy is focused on the treatment with anti-convulsants, anti-depressants, opioids, and non-opioid analgesics. A traditional Chinese medicine Wen-Luo-Tong, has been used to alleviate oxaliplatin-induced neuropathic pain for many years. Recently, Wen-Luo-Tong is found to prevent glial activation and nociceptive sensitization in a rat model of oxaliplatin-induced neuropathic pain (Deng et al., 2016b). Its ingredients including hydroxysafflor yellow A, icariin, epimedin B, and 4-dihydroxybenzoic acid increase the viability of Schwann cells injured by oxaliplatin. Microemulsion formulation containing these ingredients also decreases oxaliplatin-induced mechanical hyperalgesia responses in rat model (Lin et al., 2017). Liu-Jun-Zi-Tang is a traditional herbal medicine widely used in East Asia and clinically applied to treat functional dyspepsia and depression. Recently, it is reported to attenuate cisplatin-induced thermal hyperalgesia in mice and apoptosis in human neuroblastoma SH-SY5Y cells, showing its prevention of cisplatin-induced neurotoxicity, possibly through anti-oxidation and mitochondrial function regulation (Chiou et al., 2018). A Mexican medicinal plant Tithonia tubaeformis is used for the treatment of rheumatism and stomachache. Its hydromethanolic extract is effective in attenuating vincristine-induced allodynia and thermal hyperalgesia in mice, relieving chemotherapyinduced peripheral neuropathy (Nawaz et al., 2018). Hypericum perforatum (St. John's Wort) is used for centuries as a natural remedy for the treatment of a variety of disorders including depression (Asgary et al., 2012; Abtahi Froushani et al., 2015). It can reduce oxaliplatin-induced caspase- 3 activity in rat astrocytes, but its alone produces a cytotoxic effect and fails to reduce the cytotoxicity of oxaliplatin in HT-29 cancer cells (Cinci et al., 2017). Its main constituent hypericin is a potent inhibitor of glioma growth in vitro. In patients with documented recurrent or progressive malignant gliomas who have received standard 
TABLE 6 | Natural products in reducing chemotherapy and radiotherapy-induced cardiotoxicity.

\begin{tabular}{|c|c|c|c|c|}
\hline Name & Effect/Mechanism & $\begin{array}{l}\text { Experimental } \\
\text { setting/Model }\end{array}$ & Ingredients/Source & References \\
\hline Sheng-Mai-San & $\begin{array}{l}\text { Improvement of the } \\
\text { syndrome of qi and yin } \\
\text { deficiency, heart function } \\
\text { and the quality of life of } \\
\text { cancer patients }\end{array}$ & Patients & $\begin{array}{l}\text { Made from Ginseng radis, Liriope spicata, and } \\
\text { Schizandrae fructus } \\
\text { Main chemical constituents: ginsenoside Rg, } \\
\text { ginsenoside } \mathrm{Re} \text { and schisandrin }\end{array}$ & Lo et al., 2012 \\
\hline $\begin{array}{l}\text { Dan-Hong } \\
\text { injection }\end{array}$ & $\begin{array}{l}\text { Improvement of energy } \\
\text { metabolism and reduction } \\
\text { of oxidative stress }\end{array}$ & $\begin{array}{l}\text { Doxorubicin-induced } \\
\text { cardiotoxicity in } \mathrm{H} 9 \mathrm{c} 2 \text { cells }\end{array}$ & $\begin{array}{l}\text { Made from Radix Salviae miltiorrhizae and Flos } \\
\text { Carthami tinctorii } \\
\text { Main chemical constituents: catechol, } \\
\text { tanshinone, salvianic aid A, Carthamin and } \\
\text { carthamin yellow }\end{array}$ & Yi et al., 2018 \\
\hline $\begin{array}{l}\text { San-Yang-Xue-Dai } \\
\text { mixture }\end{array}$ & $\begin{array}{l}\text { Inhibition of ROS-mediated } \\
\text { p53 and MAPK signal } \\
\text { pathways }\end{array}$ & $\begin{array}{l}\text { Doxorubicin-induced } \\
\text { cardiotoxicity in mice }\end{array}$ & $\begin{array}{l}\text { Made from Daemonorops draco, Panax } \\
\text { notoginseng, Scoparia dulcis, Aralia cordata, } \\
\text { Alpinia ofcinarum, Dioscorea opposita, } \\
\text { Wolfporia extensa, and Amomum villosum }\end{array}$ & Chen et al., 2018 \\
\hline $\begin{array}{l}\text { Fermented } C . \\
\text { sinensis }\end{array}$ & $\begin{array}{l}\text { Inhibition of myocardial } \\
\text { hypertrophy and myocardial } \\
\text { damage, Improvement of } \\
\text { systolic function, the } \\
\text { antioxidant enzyme system, } \\
\text { and cardiac energy } \\
\text { metabolism, upregulation of } \\
\text { the cAMP and AMPK } \\
\text { signaling pathways }\end{array}$ & $\begin{array}{l}\text { Doxorubicin-induced } \\
\text { cardiotoxicity in rats }\end{array}$ & $\begin{array}{l}\text { Protein, carbohydrate, fat, ash, cordycepin, } \\
\mathrm{H} 2 \mathrm{O} \text {, amino acid, and adenosine }\end{array}$ & Wu et al., 2018 \\
\hline Diethyl blechnic & Anti-oxidation & $\begin{array}{l}\text { Doxorubicin-induced } \\
\text { apoptosis c and primary rat } \\
\text { cardiomyocytes }\end{array}$ & A main compound isolated from S. miltiorrhiza & Yu et al., $2018 \mathrm{a}$ \\
\hline Curcumin & $\begin{array}{l}\text { Upregulation of } 14-3-3 \gamma \\
\text { expression }\end{array}$ & $\begin{array}{l}\text { Doxorubicin-induced } \\
\text { cardiotoxicity in mice and } \\
\text { primary cardiomyocytes }\end{array}$ & Bioactive constituent of Curcuma longa L. & He et al., 2018 \\
\hline Saponin dioscin & $\begin{array}{l}\text { Regulation of } \\
\text { miR-140-5p-mediated } \\
\text { myocardial oxidative stress }\end{array}$ & $\begin{array}{l}\text { Doxorubicin-induced } \\
\text { cardiotoxicity in } \mathrm{H} 9 \mathrm{c} 2 \text { cells } \\
\text { and rats }\end{array}$ & Found abundantly in legumes and yams & Zhao et al., 2018 \\
\hline $\begin{array}{l}\text { Modified } \\
\text { Zhi-Gan-Cao-Tang }\end{array}$ & $\begin{array}{l}\text { Nourish heart yin and yang, } \\
\text { anti-oxidation and inhibition } \\
\text { of } \mathrm{Na}^{+} / \mathrm{K}^{+} \text {-ATPase }\end{array}$ & $\begin{array}{l}\text { Anthracycline-induced } \\
\text { congestive heart failure in an } \\
\text { 18-year-old adolescent male }\end{array}$ & $\begin{array}{l}\text { Radix Glycyrrhizae, Radix Ginseng, Fructus } \\
\text { Jujubae, Radix Rehmanniae, Radix } \\
\text { Ophiopogonis, Colla Corii Asini, Fructus } \\
\text { Cannalis, Ramulus Cinnamomi, Rhizoma } \\
\text { Zingiberis Recens, Carapax Trionycis, Plastrum } \\
\text { Testudinis, Concha Ostreae, and Radix } \\
\text { Paeoniae alba }\end{array}$ & Wu et al., 2015 \\
\hline P. grandiflorum & Anti-oxidation & $\begin{array}{l}\text { Early breast cancer } \\
\text { receiving } \\
\text { anthracycline-based } \\
\text { chemotherapy }\end{array}$ & Triterpenoid saponin, carbohydrates, and fibers & Hao et al., 2017 \\
\hline Flaxseed oil & $\begin{array}{l}\text { Maintenance of the proper } \\
\text { balance between } \\
\text { pro-oxidant/antioxidant } \\
\text { defense systems }\end{array}$ & $\begin{array}{l}\text { Arsenic-induced cardiac } \\
\text { toxicity in rats }\end{array}$ & Polyunsaturated fatty acid alpha-linolenic acid & $\begin{array}{l}\text { Varghese et al., } \\
2017\end{array}$ \\
\hline Parsley oil & $\begin{array}{l}\text { Anti-oxidation and } \\
\text { anti-inflammation and } \\
\text { anti-apoptotic }\end{array}$ & $\begin{array}{l}\text { Cisplatin-induced hepatic } \\
\text { and cardiac injuries in rats }\end{array}$ & $\begin{array}{l}\text { Phenolic compounds, particularly flavonoids } \\
\text { (e.g., apigenin, apiin, and 600-acetylapiin), } \\
\text { coumarins, furocoumarins, and essential oil } \\
\text { components (mainly myristicin and apiol) }\end{array}$ & $\begin{array}{l}\text { Abdellatief et al., } \\
2017\end{array}$ \\
\hline $\begin{array}{l}\text { Blueberry } \\
\text { anthocyanins- } \\
\text { enriched } \\
\text { extracts }\end{array}$ & $\begin{array}{l}\text { Anti-oxidation and } \\
\text { anti-inflammation }\end{array}$ & $\begin{array}{l}\text { Cyclophosphamide-induced } \\
\text { cardiac injury in rats }\end{array}$ & $\begin{array}{l}\text { 3-glycosidic derivatives of cyanidin, delphinidin, } \\
\text { malvidin, petunidin, and peonidin }\end{array}$ & Liu et al., 2015 \\
\hline R. cordifolia & Anti-oxidation & $\begin{array}{l}\text { Cyclophosphamide-induced } \\
\text { cardiac injury in rats }\end{array}$ & $\begin{array}{l}\text { Alkaloids, flavonoids, saponins, and } \\
\text { anthraquinones }\end{array}$ & $\begin{array}{l}\text { Chandrashekar } \\
\text { et al., } 2018\end{array}$ \\
\hline Black grape juice & Anti-oxidation & $\begin{array}{l}\text { Whole body } \\
\gamma \text {-irradiation-induced heart } \\
\text { toxicity of rats }\end{array}$ & $\begin{array}{l}\text { Phenolics, flavonoids, tannin, gallic acid, } \\
\text { catechin, resveratrol, caffeic acid, ellagic acid, } \\
\text { quercetin, kaempferol }\end{array}$ & $\begin{array}{l}\text { de Freitas et al., } \\
2013\end{array}$ \\
\hline
\end{tabular}


TABLE 6 | Continued

\begin{tabular}{|c|c|c|c|c|}
\hline Name & Effect/Mechanism & $\begin{array}{l}\text { Experimental } \\
\text { setting/Model }\end{array}$ & Ingredients/Source & References \\
\hline $\begin{array}{l}\text { Sheng-Mai } \\
\text { Zingerone }\end{array}$ & $\begin{array}{l}\text { Decrease of caspase-3 } \\
\text { gene expression and the } \\
\text { prominent nuclear DNA } \\
\text { fragmentation as well as } \\
\text { increase of mitochondrial } \\
\text { complexes' activities }\end{array}$ & $\begin{array}{l}\text { Cisplatin- or } \\
\gamma \text {-radiation-induced } \\
\text { cardiotoxicity in rats }\end{array}$ & A active components of ginger & $\begin{array}{l}\text { Soliman et al., } \\
2018\end{array}$ \\
\hline Hesperidin & $\begin{array}{l}\text { Inhibition of cellular damage } \\
\text { and oxidative stress }\end{array}$ & $\begin{array}{l}\gamma \text {-radiation-induced tissue } \\
\text { damage in Sprague-Dawley } \\
\text { rats }\end{array}$ & $\begin{array}{l}\text { Isolated from the ordinary orange Citrus } \\
\text { aurantium and other species of the genus } \\
\text { Citrus }\end{array}$ & $\begin{array}{l}\text { Pradeep et al., } \\
2012\end{array}$ \\
\hline
\end{tabular}

radiation therapy with or without chemotherapy, oral hypericin is well-tolerated (Couldwell et al., 2011), suggesting that $H$. perforatum is used as a therapeutic strategy for counteracting chemotherapy and radiotherapy-induced neuropathy. Natural bicyclic sesquiterpenes, $\beta$-caryophyllene and $\beta$-caryophyllene oxide are found in a large number of plants worldwide. They possess neuropharmacological effects as chemo-sensitizing agents for doxorubicin chemotherapy and re-sensitize cancerresistant cells (Di Giacomo et al., 2017). A therapeutic plant Lithospermi radix (the root of Lithospermum erythrorhizon) is used to treat septic shock, eczema, and burns. Its water extract restores oxaliplatin-induced neurotoxicity in nerve growth factor-stimulated neurite outgrowth in PC12 cells and animals with enhanced nociceptive sensitivity to mechanical stimuli along with spinal activation of microglias and astrocytes as well as loss of intraepidermal nerve fibers of footpads (Cho et al., 2016). $\beta$-Caryophyllene also effectively attenuates paclitaxelinduced peripheral neuropathy in mice, possibly through $\mathrm{CB}_{2}$-activation in the central nervous system and posterior inhibition of p38 MAPK/NF- $\kappa$ B activation (Segat et al., 2017). Curcumin also has neuroprotective action. In 2017, Rezaee et al. provide a summary of the studies done to show the protective effects of curcumin against cisplatin-induced neurotoxicity, nephrotoxicity and ototoxicity (Rezaee et al., 2017). Its natural derivative demethoxycurcumin exhibits neuroprotective effect in rotenone-induced neurotoxicity in SH-SY5Y neuroblastoma cells (Ramkumar et al., 2017). 5, 7-Dihydroxyflavone (Chrysin), a natural plant flavonoid, has neuroprotective effect against $\gamma$-irradiation induced-neurotoxicity in rats (Mansour et al., 2017). Shikonin, a natural naphthoquinone compound, is one of the main chemicals isolated from Lithospermi radix. Shikonin and its derivatives suppress the epidermal growth factor receptor signaling and synergistically kill glioblastoma cells in combination with erlotinib, possibly being a potential strategy to overcome drug resistance to erlotinib (Zhao et al., 2015). Oxidative damage contributes to cisplatin-induced neurotoxicity. As an apoptotic inhibitor, natural flavonoid compound cyanidin effectively restores cisplatin-induced neurotoxicity through inhibition of ROS-mediated DNA damage and apoptosis (Li et al., 2015).

Dietary supplement OPERA ${ }^{\circledR}$ containing $\alpha$-lipoic acid, Boswellia Serrata, methylsulfonylmethane and bromelain, is able to improve chemotherapy-induced peripheral neuropathy symptoms in a prospective series of patients treated with neurotoxic chemotherapy, without significant toxicity or interaction (Desideri et al., 2017). A systematic review of preclinical studies demonstrate that grape seed extract can treat chemotherapy and radiotherapy-induced neurotoxicity (Olaku et al., 2015). Clinical trial demonstrates that green tea consumption with neuroprotective effect has anticancer action via regulation of intra-tumoural lymph-angiogenesis and COX-2 expression (Najaf Najafi et al., 2018). These diet supplements may be effective in the prevention or treatment of chemotherapy and radiotherapy-induced neurotoxicity.

However, in 2017, Schloss et al. provide review that there is no solid beneficial evidence for herb medicine which is recommended for the prevention or treatment of chemotherapyinduced peripheral neuropathy (Schloss et al., 2017). In fact, in 2015, Oki et al. conduct a placebo-controlled, doubleblind, randomized phase III study and observe no effects of Goshajinkigan on oxaliplatin-associated peripheral neuropathy in patients with colorectal cancer (Oki et al., 2015). Consistently, in 2017, Kuriyama et al. conduct a systematic review and meta-analysis, and further demonstrate that Goshajinkigan is impossible to prevent peripheral neuropathy in patients receiving neurotoxic chemotherapy. Next, Hoshino et al. also conduct a systematic review and show that Goshajinkigan tends to prevent persistence but not severity of chemotherapy-induced peripheral neuropathy (Hoshino et al., 2018). Given the low quality and insufficient amount of the evidence, use of Goshajinkigan as standard of care is not currently recommended (Kuriyama and Endo, 2018). On the other hand, although phytochemicals, medicinal herbs, and their formulas may be considered for prophylaxis of chemotherapy-induced peripheral neuropathy, the curative usability as well as the reciprocal effect with other drug should be examined in well-designed clinical trials (Lee and Kim, 2016). The natural products in this part together with relevant characteristics of the respective studies are summarized in Table 7.

\section{LIMITATIONS}

Recent efforts to prevent chemotherapy and radiotherapyinduced side effects have used natural products with biochemical 
TABLE 7 | Natural products in reducing chemotherapy and radiotherapy-induced neurotoxicity.

\begin{tabular}{|c|c|c|c|c|}
\hline Name & Effect/Mechanism & $\begin{array}{l}\text { Experimental } \\
\text { setting/Model }\end{array}$ & Ingredients/Source & References \\
\hline Ai-Di injection & $\begin{array}{l}\text { Improvement of overall response } \\
\text { rate and quality of life, reduction } \\
\text { of the incidence of peripheral } \\
\text { neurotoxicity (III-IV) }\end{array}$ & Patients & $\begin{array}{l}\text { made from the extracts of Mylabris phalerata, } \\
\text { Radix astragalus, Radix ginseng, and } \\
\text { Acanthopanax senticosus }\end{array}$ & Ge et al., 2016 \\
\hline $\begin{array}{l}\text { Shen-Qi-Fu-Zheng } \\
\text { injection }\end{array}$ & $\begin{array}{l}\text { Improvement of overall response } \\
\text { rate and quality of life, reduction } \\
\text { of the incidence of peripheral } \\
\text { neurotoxicity (III-IV) }\end{array}$ & Patients & $\begin{array}{l}\text { Made from the extracts of Radix Astragali and } \\
\text { Radix Codonopsis }\end{array}$ & Ge et al., 2016 \\
\hline Matrine injection & $\begin{array}{l}\text { Improvement of overall response } \\
\text { rate and quality of life, reduction } \\
\text { of the incidence of peripheral } \\
\text { neurotoxicity (III-IV) }\end{array}$ & Patients & $\begin{array}{l}\text { Major component of the traditional Chinese } \\
\text { herb Sophora flavescens }\end{array}$ & Ge et al., 2016 \\
\hline TJ107 and TJ68 & $\begin{array}{l}\text { TJ107 has antinociceptive } \\
\text { effects caused by increased } \\
\text { nitric oxide production and } \\
\text { induction of dynorphin release in } \\
\text { the spinal cord; the } \\
\text { antinociceptive effects of TJ68 } \\
\text { have been attributed to the } \\
\text { activation of spinal-descending } \\
\text { noradrenergic neurons }\end{array}$ & Patients & $\begin{array}{l}\text { TJ107 consists of Rehmanniae radix, } \\
\text { Achyranthis radix, Corni fructus, Moutan } \\
\text { cortex, Alismatics rhizome, Dioscoreae } \\
\text { rhizome, Plantaginis semen, Hoelen, processed } \\
\text { Aconiti tuber, and Cinnamomi cortex, which } \\
\text { includes magnesium stearate, lactose, and } \\
\text { fructose fatty acid esters as diluents } \\
\text { TJ68 is composed of Paeoniae Radix and } \\
\text { Glycyrrhizae Radix } \\
\text { Main chemical constituents: albiflorin, } \\
\text { paeoniflorin, glycycoumarin, isoliquiritigenin, } \\
\text { glycyrrhetic acid, and glycyrrhetic } \\
\text { acid-3-O-monoglucuronide }\end{array}$ & $\begin{array}{l}\text { Hosokawa et al., } \\
2012\end{array}$ \\
\hline Radix Astragali & $\begin{array}{l}\text { Relieve of pain and promote of } \\
\text { the rescue mechanisms }\end{array}$ & $\begin{array}{l}\text { Oxaliplatin-induced } \\
\text { neuropathy of rats }\end{array}$ & Astragalosides & $\begin{array}{l}\text { Mannelli et al., } \\
2017\end{array}$ \\
\hline Wen-Luo-Tong & Unknown & $\begin{array}{l}\text { Oxaliplatin-treated rats and } \\
\text { Schwann cells }\end{array}$ & $\begin{array}{l}\text { Made from Epimedium herb, Geranium } \\
\text { wilfordii, Cassia twig and Carthamus tinctorius } \\
\text { Main chemical constituents: hydroxysafflor } \\
\text { yellow A, icariin, epimedin B and } \\
\text { 4-dihydroxybenzoic acid }\end{array}$ & Lin et al., 2017 \\
\hline Liu-Jun-Zi-Tang & $\begin{array}{l}\text { Anti-oxidation and mitochondrial } \\
\text { function regulation }\end{array}$ & $\begin{array}{l}\text { Cisplatin treated mice and } \\
\text { human neuroblastoma } \\
\text { SH-SY5Y cells }\end{array}$ & $\begin{array}{l}\text { Made from Ginseng, Atractylodes, Poria cocos, } \\
\text { Glycyrrhizae, Pericarpium Citri Reticulatae, and } \\
\text { Pinellia ternata } \\
\text { Main chemical constituents: succinic acid, } \\
\text { hesperidin, ginsenoside Rb1, glycyrrhizic acid I, } \\
\text { 2-atractylenolide and pachymic acid }\end{array}$ & Chiou et al., 2018 \\
\hline T. tubaeformis & Anti-nociception & Vincristine-treated mice & $\begin{array}{l}\text { Tagitinin A-C and F, diversifol and tithonine } \\
\text { chromene, and flavone derivatives }\end{array}$ & Nawaz et al., 2018 \\
\hline H. perforatum & Glioma growth inhibition & Patients & $\begin{array}{l}\text { Hypericin, pseudohypericin, flavonoids, } \\
\text { oligomeric procyanidins, and hyperforin }\end{array}$ & $\begin{array}{l}\text { Couldwell et al., } \\
2011\end{array}$ \\
\hline$\beta$-caryophyllene & $\begin{array}{l}\mathrm{CB}_{2} \text {-activation and inhibition of } \\
\text { p38 MAPK/NF-кB activation }\end{array}$ & Paclitaxel-treated mice & Found in various plants & Segat et al., 2017 \\
\hline Lithospermi radix & Anti-inflammation & $\begin{array}{l}\text { PC12 cells and animals } \\
\text { induced by oxaliplatin }\end{array}$ & Furylhydroquinone derivatives and shikonin & Cho et al., 2016 \\
\hline Curcumin & $\begin{array}{l}\text { Reduction of lipid peroxidation, } \\
\text { maintenance of the balance of } \\
\text { catalase, glutathione peroxidase } \\
\text { and superoxide dismutase, and } \\
\text { anti-oxidation }\end{array}$ & Rats & Bioactive constituent of Curcuma longa L. & $\begin{array}{l}\text { Rezaee et al., } \\
2017\end{array}$ \\
\hline Demethoxycurcumin & $\begin{array}{l}\text { Suppression of apoptosis by } \\
\text { regulating pro and anti-apoptotic } \\
\text { indices and attenuating oxidative } \\
\text { stress and mitochondrial } \\
\text { dysfunction }\end{array}$ & $\begin{array}{l}\text { Rotenone-induced } \\
\text { neurotoxicity in SH-SY5Y } \\
\text { neuroblastoma cells }\end{array}$ & Curcumin analog & $\begin{array}{l}\text { Ramkumar et al., } \\
2017\end{array}$ \\
\hline $\begin{array}{l}5,7- \\
\text { Dihydroxyflavone } \\
\text { (Chrysin) }\end{array}$ & $\begin{array}{l}\text { Anti-lipid peroxidative, } \\
\text { anti-amyloidogenic, and } \\
\text { anti-apoptotic effects }\end{array}$ & $\begin{array}{l}\text { Irradiation } \\
\text { induced-neurotoxicity in the } \\
\text { brain of rats }\end{array}$ & $\begin{array}{l}\text { A flavonoid content extracted from propolis, } \\
\text { honey, and plants }\end{array}$ & $\begin{array}{l}\text { Mansour et al., } \\
2017\end{array}$ \\
\hline
\end{tabular}


TABLE 7 | Continued

\begin{tabular}{|c|c|c|c|c|}
\hline Name & Effect/Mechanism & $\begin{array}{l}\text { Experimental } \\
\text { setting/Model }\end{array}$ & Ingredients/Source & References \\
\hline Shikonin & $\begin{array}{l}\text { Suppression of the epidermal } \\
\text { growth factor receptor signaling } \\
\text { and killing of glioblastoma cells }\end{array}$ & U87MG cells & Main chemicals isolated from Lithospermi radix & Zhao et al., 2015 \\
\hline Cyanidin & $\begin{array}{l}\text { Inhibition of ROS-mediated DNA } \\
\text { damage and apoptosis }\end{array}$ & PC12 cells & A flavonoid derived from cherry & Li et al., 2015 \\
\hline $\begin{array}{l}\text { Dietary } \\
\text { supplement } \\
\text { OPERA }\end{array}$ & $\begin{array}{l}\text { Anti-oxidation, anti-inflammation, } \\
\text { anti-atherosclerotic, and } \\
\text { anti-thrombotic effect }\end{array}$ & Patients & $\begin{array}{l}\alpha \text {-lipoic acid, boswellia serrata, } \\
\text { methylsulfonylmethane, and bromelain }\end{array}$ & $\begin{array}{l}\text { Desideri et al., } \\
2017\end{array}$ \\
\hline $\begin{array}{l}\text { Grape seed } \\
\text { proanthocyanidins }\end{array}$ & Anti-oxidation & Mice, rats, and cells & $\begin{array}{l}\text { Rich in polyphenols of which about } 60 \% \text { to } \\
70 \% \text { is found in grape seeds as dimers, } \\
\text { trimers, and other oligomers of flavan-3-ols, } \\
\text { known commonly as proanthocyanidins }\end{array}$ & Olaku et al., 2015 \\
\hline Green tea & $\begin{array}{l}\text { Regulation of intra-tumoural } \\
\text { lymph-angiogenesis and } \\
\text { expression of COX-2 }\end{array}$ & Patients & Catechins & $\begin{array}{l}\text { Najaf Najafi et al., } \\
2018\end{array}$ \\
\hline $\begin{array}{l}\text { Goshajinkigan } \\
\text { (TJ107) }\end{array}$ & $\begin{array}{l}\text { No effects of Goshajinkigan on } \\
\text { oxaliplatin-associated peripheral } \\
\text { neuropathy in patients with } \\
\text { colorectal cancer }\end{array}$ & Patients & $\begin{array}{l}\text { Rehmanniae radix, Achyranthis radix, Corni } \\
\text { fructus, Moutan cortex, Alismatics rhizome, } \\
\text { Dioscoreae rhizome, Plantaginis semen, } \\
\text { Hoelen, processed Aconiti tuber, and } \\
\text { Cinnamomi cortex }\end{array}$ & $\begin{array}{l}\text { Oki et al., 2015; } \\
\text { Hoshino et al., } \\
\text { 2018; Kuriyama } \\
\text { and Endo, } 2018\end{array}$ \\
\hline
\end{tabular}

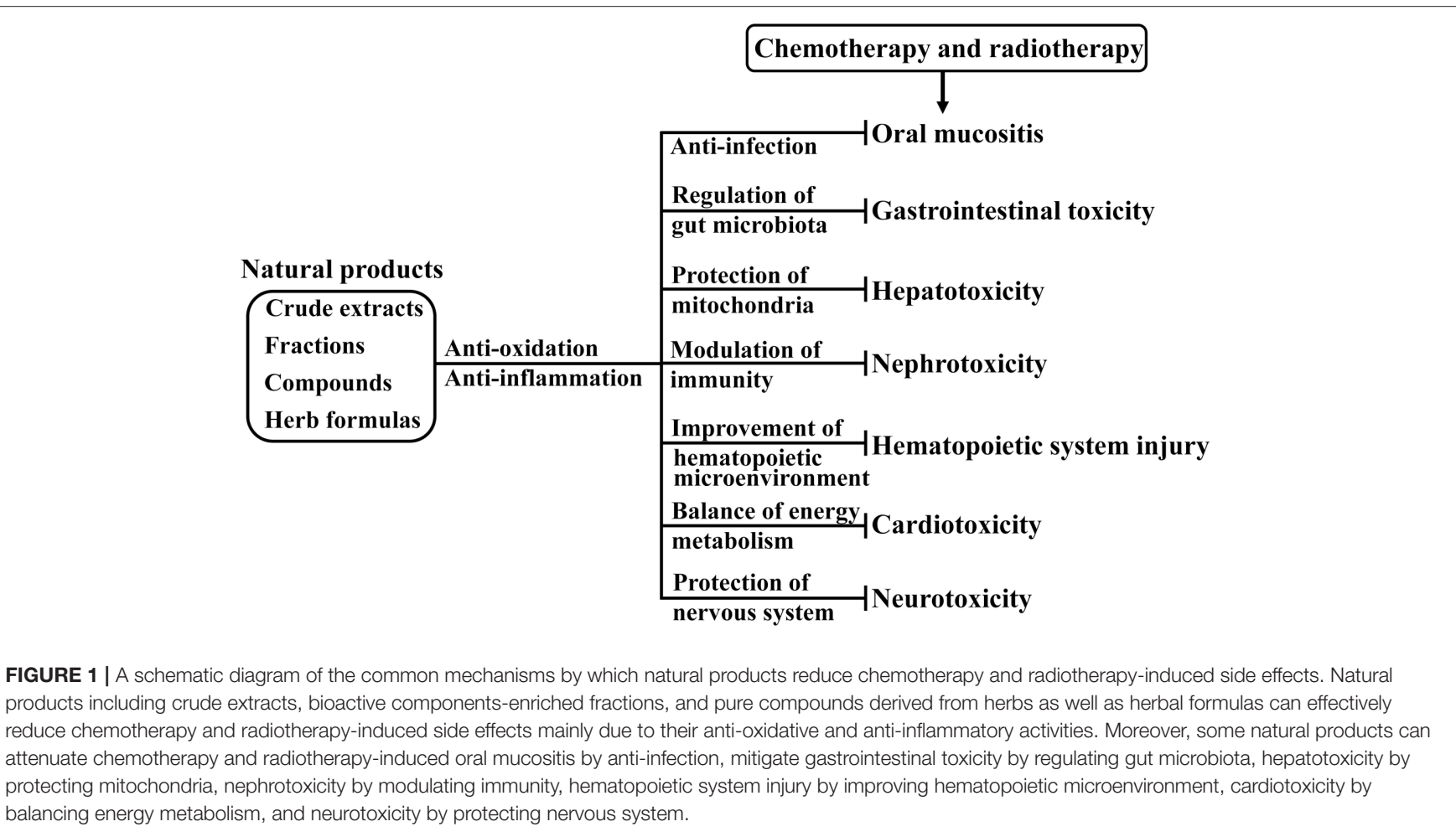

and pharmacological properties. However, there are multiple limitations. These include:

a. Lack of high quality trials using multiple measures to assess the various aspects of chemotherapy and radiotherapy-induced side effects, as well as to clarify the preventive effects of natural products. b. Preclinical models of chemotherapy and radiotherapyinduced side effects are not sufficiently to verify the prevention of natural products.

c. Need an imaged-based high-content screening platform with a protocol to find innovative natural products against chemotherapy and radiotherapy-induced side effects. 
d. Unknown molecular mechanisms of the attenuations of some natural products on chemotherapy and radiotherapy-induced side effects.

e. No strategy of the modulation of gut microbiota by natural products to control chemotherapy and radiotherapy-induced side effects.

f. Unknown the biological mechanisms of interaction between chemotherapy drugs and natural products.

g. Need to ascertain natural products-evoked toxicity.

\section{CONCLUSION}

There is the evidence that natural products can reduce chemotherapy and radiotherapy-induced side effects such as oral mucositis, gastrointestinal toxicity, hepatotoxicity, nephrotoxicity, hematopoietic system injury, cardiotoxicity, and neurotoxicity (Figure 1). The summarized data have also highlighted the efficacy of natural dietary supplements to counteract these side effects. Thus, these products including dietary supplements should be used as an alternative therapeutic strategy for the prophylaxis and treatment of

\section{REFERENCES}

Abaza, M. S., Orabi, K. Y., Al-Quattan, E., and Al-Attiyah, R. J. (2015). Growth inhibitory and chemo-sensitization effects of naringenin, a natural flavanone purified from Thymus vulgaris, on human breast and colorectal cancer. Cancer Cell Int. 15:46. doi: 10.1186/s12935-015-0194-0

Abd El-Azime, A. S., Hussein, E. M., and Ashry, O. M. (2014). Synergestic effect of aqueous purslane (Portulaca oleracea L.) extract and fish oil on radiation-induced damage in rats. Int. J. Radiat. Biol. 90, 1184-1190. doi: 10.3109/09553002.2014.926040

Abdellatief, S. A., Galal, A. A., Farouk, S. M., and Abdel-Daim, M. M. (2017). Ameliorative effect of parsley oil on cisplatin-induced hepato-cardiotoxicity: a biochemical, histopathological, and immunohistochemical study. Biomed. Pharmacother. 86, 482-491. doi: 10.1016/j.biopha.2016.12.038

Abtahi Froushani, S. M., Esmaili Gouvarchin Galee, H., Khamisabadi, M., and Lotfallahzade, B. (2015). Immunomudulatory effects of hydroalcoholic extract of Hypericum perforatum. Avicenna. J. Phytomed. 5, 62-68. doi: 10.1007/s00044-016-1702-z

Adaramoye, O. A., Okiti, O. O., and Farombi, E. O. (2011). Dried fruit extract from Xylopia aethiopica (Annonaceae) protects Wistar albino rats from adverse effects of whole body radiation. Exp. Toxicol. Pathol. 63, 635-643. doi: 10.1016/j.etp.2010.05.005

Adom, M. B., Taher, M., Mutalabisin, M. F., Amri, M. S., Abdul Kudos, M. B., Wan Sulaiman, M. W. A., et al. (2017). Chemical constituents and medical benefits of Plantago major. Biomed. Pharmacother. 96, 348-360. doi: 10.1016/j.biopha.2017.09.152

Al Dhaheri, Y., Attoub, S., Ramadan, G., Arafat, K., Bajbouj, K., Karuvantevida, $\mathrm{N}$, et al. (2014). Carnosol induces ROS-mediated beclin1-independent autophagy and apoptosis in triple negative breast cancer. PLoS ONE 9:e109630. doi: 10.1371/journal.pone. 0109630

Al Dhaheri, Y., Eid, A., Abuqamar, S., Attoub, S., Khasawneh, M., Aiche, G., et al. (2013). Mitotic arrest and apoptosis in breast cancer cells induced by Origanum majorana extract: upregulation of TNF-alpha and downregulation of survivin and mutant p53. PLOS ONE 8:e56649. doi: 10.1371/journal.pone. 0056649

Al Jaouni, S. K., Al Muhayawi, M. S., Hussein, A., Elfiki, I., Al-Raddadi, R., Al Muhayawi, S. M., et al. (2017). Effects of honey on oral mucositis among pediatric cancer patients undergoing chemo/radiotherapy treatment at King Abdulaziz University Hospital in Jeddah, Kingdom of Saudi Arabia. chemotherapy and radiotherapy-induced side effects in cancer patients.

However, this issue is still controversial in underlying the efficacy conducted by different analysis and clinical trials in selected cancer patients. The difficulty in the revealing the molecular mechanisms has so far hampered the understanding of the attenuation of chemotherapy and radiotherapy-induced side effects in clinical use of natural products (Anwar et al., 2016).

Of note, new therapies in clinical validation phases are investigating gut microbiota fighting against many diseases, and forming the targets of chemotherapy and radiotherapy-induced toxicity. These studies may help to shed light upon the preventive process of chemotherapy and radiotherapy-induced side effects by natural products and develop the available intervention for cancer patients for the managements.

\section{AUTHOR CONTRIBUTIONS}

LD-K conceived and designed the review. L-DK, Q-YZ, F-XW, and $\mathrm{K}-\mathrm{KJ}$ performed the literature search. L-DK, F-XW, and $\mathrm{Q}-\mathrm{YZ}$ analyzed and wrote the paper.
Evid. Based. Complement. Alternat. Med. 2017:5861024. doi: 10.1155/2017/58 61024

Al-Menhali, A., Al-Rumaihi, A., Al-Mohammed, H., Al-Mazrooey, H., AlShamlan, M., Aljassim, M., et al. (2015). Thymus vulgaris (thyme) inhibits proliferation, adhesion, migration, and invasion of human colorectal cancer cells. J. Med. Food 18, 54-59. doi: 10.1089/jmf.2013.3121

Anwar, M. A., Al Disi, S. S., and Eid, A. H. (2016). Anti-hypertensive herbs and their mechanisms of action: part II. Front. Pharmacol. 7:50. doi: 10.3389/fphar.2016.00050

Asgary, S., Solhpour, A., Parkhideh, S., Madani, H., Mahzouni, P., and Kabiri, N. (2012). Effect of hydroalcoholic extract of Hypericum perforatum on selected traditional and novel biochemical factors of cardiovascular diseases and atherosclerotic lesions in hypercholesterolemic rabbits: a comparison between the extract and lovastatin. J. Pharm. Bioallied. Sci. 4, 212-218. doi: 10.4103/0975-7406.99044

Athamneh, K., Hasasna, H. E., Samri, H. A., Attoub, S., Arafat, K., Benhalilou, N., et al. (2017). Rhus coriaria increases protein ubiquitination, proteasomal degradation and triggers non-canonical Beclin-1-independent autophagy and apoptotic cell death in colon cancer cells. Sci. Rep. 7:11633. doi: 10.1038/s41598-017-11202-3

Ayesh, B. M., Abed, A. A., and Faris, D. M. (2014). In vitro inhibition of human leukemia THP-1 cells by Origanum syriacum L. and Thymus vulgaris $L$. extracts. BMC Res. 7:612. doi: 10.1186/1756-0500-7-612

Bagchi, D., Swaroop, A., Preuss, H. G., and Bagchi, M. (2014). Free radical scavenging, antioxidant and cancer chemoprevention by grape seed proanthocyanidin: an overview. Mutat. Res. 768, 69-73. doi: 10.1016/j.mrfmmm.2014.04.004

Benzer, F., Kandemir, F. M., Ceribasi, S., Ozkaraca, M., Yildirim, N. C., and Ozan, S. T. (2012). Chemotherapeutic agent-induced nephrotoxicity in rabbits: protective role of grape seed extract. Int. J. Pharmacol. 8, 39-45. doi: 10.3923/ijp.2012.39.45

Bing, S. J., Ha, D., Kim, M. J., Park, E., Ahn, G., Kim, D. S., et al. (2013) Geraniin down regulates gamma radiation-induced apoptosis by suppressing DNA damage. Food Chem. Toxicol. 57, 147-153. doi: 10.1016/j.fct.2013.03.022

Bruneau, A., Baylatry, M. T., Joly, A. C., and Sokol, H. (2018). Gut microbiota: what impact on colorectal carcinogenesis and treatment? Bull. Cancer 105, 70-80. doi: 10.1016/j.bulcan.2017.10.025

Budhani, M. K., Dahiya, V., Bodduluru, L. N., Kasala, E. R., Bezbaruah, B. K., and Lahkar, M. (2014). Hesperetin attenuates cisplatin induced nephrotoxicity 
via modulation of oxidative stress and renal inflammation in male wistar rats. Indian J. Pharmacol. 46:S62.

Cabrera-Jaime, S., Martinez, C., Ferro-Garcia, T., Giner-Boya, P., Icart-Isern, T., Estrada-Masllorens, J. M., et al. (2018). Efficacy of Plantago major, chlorhexidine $0.12 \%$ and sodium bicarbonate $5 \%$ solution in the treatment of oral mucositis in cancer patients with solid tumour: a feasibility randomised triple-blind phase III clinical trial. Eur. J. Oncol. Nurs. 32, 40-47. doi: 10.1016/j.ejon.2017.11.006

Canyilmaz, E., Uslu, G. H., Bahat, Z., Kandaz, M., Mungan, S., Haciislamoglu, E., et al. (2016). Comparison of the effects of melatonin and genistein on radiation-induced nephrotoxicity: results of an experimental study. Biomed. Rep. 4, 45-50. doi: 10.3892/br.2015.547

Cascella, M., Palma, G., Barbieri, A., Bimonte, S., Amruthraj, N. J., Muzio, M. R., et al. (2017). Role of Nigella sativa and its constituent thymoquinone on chemotherapy-induced nephrotoxicity: Evidences from experimental animal studies. Nutrients 9:E625. doi: 10.3390/nu9060625

Chacko, T., Menon, A., Majeed, T., Nair, S. V., John, N. S., and Nair, C. K. K. (2017). Mitigation of whole-body gamma radiation-induced damages by Clerodendron infortunatum in mammalian organisms. J. Radiat. Res. 58, 281-291. doi: 10.1093/jrr/rrw093

Chandrashekar, B. S., Prabhakara, S., Mohan, T., Shabeer, D., Bhandare, B., Nalini, M., et al. (2018). Characterization of Rubia cordifolia L. root extract and its evaluation of cardioprotective effect in Wistar rat model. Indian J. Pharmacol. 50, 12-21. doi: 10.4103/ijp.IJP_418_17

Chen, M. H., May, B. H., Zhou, I. W., Zhang, A. L., and Xue, C. C. (2016). Integrative medicine for relief of nausea and vomiting in the treatment of colorectal cancer using oxaliplatin-based chemotherapy: a systematic review and meta-analysis. Phytother. Res. 30, 741-753. doi: 10.1002/ptr.5586

Chen, Q. Q., Han, X., Wang, W. M., Zhao, L., and Chen, A. (2015). Danggui sini decoction ameliorates myelosuppression in animal model by upregulating Thrombopoietin expression. Cell Biochem. Biophys. 71, 945-950. doi: 10.1007/s12013-014-0291-Z

Chen, T., Deng, Z., Zhao, R., Shen, H., and Li, W. (2018). SYKT Alleviates doxorubicin-induced cardiotoxicity via modulating ROS-Mediated p53 and MAPK signal pathways. Evid. Based Complement. Alternat. Med. 2018:2581031. doi: 10.1155/2018/2581031

Chen, T., Shen, H. M., Deng, Z. Y., Yang, Z. Z., Zhao, R. L., Wang, L., et al. (2017). A herbal formula, SYKT, reverses doxorubicininduced myelosuppression and cardiotoxicity by inhibiting ROSmediated apoptosis. Mol. Med. Rep. 15, 2057-2066. doi: 10.3892/mmr.2017.6272

Chen, X., Li, B., Gao, Y., Ji, J., Wu, Z., and Chen, S. (2017). Saponins from Sanguisorba officinalis improve hematopoiesis by promoting survival through FAK and Erk1/2 activation and modulating cytokine production in bone marrow. Front. Pharmacol. 8:130. doi: 10.3389/fphar.2017.00130

Chen, Y., Zheng, H., Zhang, J., Wang, L., Jin, Z., and Gao, W. (2016). Protective effect and potential mechanisms of Wei-Chang-An pill on high-dose 5fluorouracil-induced intestinal mucositis in mice. J. Ethnopharmacol. 190, 200-211. doi: 10.1016/j.jep.2016.05.057

Chiou, C. T., Wang, K. C., Yang, Y. C., Huang, C. L., Yang, S. H., Kuo, Y. H., et al. (2018). Liu Jun Zi Tang-A potential, multi-herbal complementary therapy for chemotherapy-induced neurotoxicity. Int. J. Mol. Sci. 19:E1258. doi: $10.3390 /$ ijms 19041258

Cho, E. S., Yi, J. M., Park, J. S., Lee, Y. J., Lim, C. J., Bang, O. S., et al. (2016). Aqueous extract of Lithospermi radix attenuates oxaliplatin-induced neurotoxicity in both in vitro and in vivo models. BMC Complement. Altern. Med. 16:419. doi: 10.1186/s12906-016-1396-2

Cinci, L., Di Cesare Mannelli, L., Maidecchi, A., Mattoli, L., and Ghelardini, C. (2017). Effects of Hypericum perforatum extract on oxaliplatininduced neurotoxicity: in vitro evaluations. Z. Naturforsch C. 72, 219-226. doi: 10.1515/znc-2016-0194

Costa, M. L., Rodrigues, J. A., Azevedo, J., Vasconcelos, V., Eiras, E., and Campos, M. G. (2018). Hepatotoxicity induced by paclitaxel interaction with turmeric in association with a microcystin from a contaminated dietary supplement. Toxicon 150, 207-211. doi: 10.1016/j.toxicon.2018.05.022

Couldwell, W. T., Surnock, A. A., Tobia, A. J., Cabana, B. E., Stillerman, C. B., Forsyth, P. A., et al. (2011). A phase $1 / 2$ study of orally administered synthetic hypericin for treatment of recurrent malignant gliomas. Cancer 117, 4905-4915. doi: 10.1002/cncr.26123
Cui, D. N., Wang, X., Chen, J. Q., Lv, B., Zhang, P., Zhang, W., et al. (2017). Quantitative evaluation of the compatibility effects of Huangqin Decoction on the treatment of irinotecan-induced gastrointestinal toxicity using untargeted metabolomics. Front. Pharmacol. 8:211. doi: 10.3389/fphar.2017.00211

Curro, D. (2018). The role of gut microbiota in the modulation of drug action: a focus on some clinically significant issues. Expert Rev. Clin. Pharmacol. 11, 171-183. doi: 10.1080/17512433.2018.1414598

de Freitas, R. B., Boligon, A. A., Rovani, B. T., Piana, M., De Brum, T. F., Da Silva Jesus, R., et al. (2013). Effect of black grape juice against heart damage from acute gamma TBI in rats. Molecules 18, 12154-12167. doi: 10.3390/molecules181012154

Demir Dogan, M., Can, G., and Meral, R. (2017). Effectiveness of black mulberry molasses in prevention of radiotherapy-induced oral mucositis: a randomized controlled study in head and neck cancer patients. J. Altern. Complement. Med. 23, 971-979. doi: 10.1089/acm.2016.0425

Deng, B., Jia, L., and Cheng, Z. (2016a). Radix Astragali-based Chinese herbal medicine for oxaliplatin-induced peripheral neuropathy: a systematic review and meta-analysis. Evid. Based Complement. Alternat. Med. 2016:2421876. doi: $10.1155 / 2016 / 2421876$

Deng, B., Jia, L., Pan, L., Song, A., Wang, Y., Tan, H., et al. (2016b). Wen-LuoTong prevents glial activation and nociceptive sensitization in a rat model of oxaliplatin-induced neuropathic pain. Evid. Based Complement. Alternat. Med. 2016:3629489. doi: 10.1155/2016/3629489

Desideri, I., Francolini, G., Becherini, C., Terziani, F., Paoli, C. D., Olmetto, E., et al. (2017). Use of an alpha lipoic, methylsulfonylmethane and bromelain dietary supplement (Opera (R)) for chemotherapy-induced peripheral neuropathy management, a prospective study. Med. Oncol. 34:46. doi: 10.1007/s12032-017-0907-4

Di Giacomo, S., Di Sotto, A., Mazzanti, G., and Wink, M. (2017). Chemosensitizing properties of beta-caryophyllene and beta-caryophyllene oxide in combination with doxorubicin in human cancer cells. Anticancer Res. 37, 1191-1196. doi: 10.21873 /anticanres. 11433

Dodwad, V., and Kukreja, B. J. (2011). Propolis mouthwash: a new beginning. J. Indian Soc. Periodontol. 15, 121-125. doi: 10.4103/0972-124X.84379

Duan, B., Xie, J., Rui, Q., Zhang, W., and Xi, Z. (2018). Effects of Shengmai injection add-on therapy to chemotherapy in patients with non-small cell lung cancer: a meta-analysis. Support. Care Cancer 26, 2103-2111. doi: $10.1007 / \mathrm{s} 00520-018-4167-4$

El Hasasna, H., Athamneh, K., Al Samri, H., Karuvantevida, N., Al Dhaheri, Y., Hisaindee, S., et al. (2015). Rhus coriaria induces senescence and autophagic cell death in breast cancer cells through a mechanism involving p38 and ERK1/2 activation. Sci. Rep. 5:13013. doi: 10.1038/srep13013

El Hasasna, H., Saleh, A., Al Samri, H., Athamneh, K., Attoub, S., Arafat, K., et al. (2016). Rhus coriaria suppresses angiogenesis, metastasis and tumor growth of breast cancer through inhibition of STAT3, NFkappaB and nitric oxide pathways. Sci. Rep. 6:21144. doi: 10.1038/srep21144

El-Desouky, W., Hanafi, A., and Abbas, M. M. (2017). Radioprotective effect of green tea and grape seed extracts mixture on gamma irradiation induced immune suppression in male albino rats. Int. J. Radiat. Biol. 93, 433-439. doi: 10.1080/09553002.2016.1254834

Emami, H., Nikoobin, F., Roayaei, M., and Ziya, H. R. (2014). Double-blinded, randomized, placebo-controlled study to evaluate the effectiveness of green tea in preventing acute gastrointestinal complications due to radiotherapy. J. Res. Med. Sci. 19, 445-450.

Eslami, H., Pouralibaba, F., Falsafi, P., Bohluli, S., Najati, B., Negahdari, R., et al. (2016). Efficacy of Hypozalix spray and propolis mouthwash for prevention of chemotherapy-induced oral mucositis in leukemic patients: a double-blind randomized clinical trial. J. Dent. Res. Dent. Clin. Dent. Prospects 10, 226-233. doi: 10.15171 /joddd.2016.036

Fathy, S. A., Emam, M. A., Abo Agwa, S. H., Abu Zahra, F. A., Youssef, F. S., and Sami, R. M. (2016). The antiproliferative effect of Origanum majorana on human hepatocarcinoma cell line: suppression of NF-kappaB. Cell. Mol. Biol. $62,80-84$.

Frassova, Z., and Ruda-Kucerova, J. (2017). Milk thistle (Silybum Marianum) as a supportive phytotherapeutic agent in oncology. Klin. Onkol. 30, 426-432. doi: $10.14735 /$ amko2017426

Friend, A., Rubagumya, F., and Cartledge, P. (2018). Global health journal club: is honey effective as a treatment for chemotherapy-induced 
mucositis in paediatric oncology patients? J. Trop. Pediatr. 64, 162-168. doi: 10.1093/tropej/fmx092

Fujita, D., Saito, Y., Nakanishi, T., and Tamai, I. (2016). Organic anion transporting polypeptide (OATP)2B1 contributes to gastrointestinal toxicity of anticancer drug SN-38, active metabolite of irinotecan hydrochloride. Drug Metab. Dispos. 44, 1-7. doi: 10.1124/dmd.115.066712

Gao, Y., Chu, S., Shao, Q., Zhang, M., Xia, C., Wang, Y., et al. (2017). Antioxidant activities of ginsenoside $\operatorname{Rg} 1$ against cisplatin-induced hepatic injury through Nrf2 signaling pathway in mice. Free Radic. Res. 51, 1-13. doi: 10.1080/10715762.2016.1234710

Gautam, R., Singh, M., Gautam, S., Rawat, J. K., Saraf, S. A., and Kaithwas, G. (2016). Rutin attenuates intestinal toxicity induced by Methotrexate linked with anti-oxidative and anti-inflammatory effects. BMC Complement. Altern. Med. 16:99. doi: 10.1186/s12906-016-1069-1

Ge, L., Wang, Y. F., Tian, J. H., Mao, L., Zhang, J., Zhang, J. H., et al. (2016). Network meta-analysis of Chinese herb injections combined with FOLFOX chemotherapy in the treatment of advanced colorectal cancer. J. Clin. Pharm. Ther. 41, 383-391. doi: 10.1111/jcpt.12410

Gomes, V. T. S., Nonato Silva Gomes, R., Gomes, M. S., Joaquim, W. M., Lago, E. C., and Nicolau, R. A. (2018). Effects of Matricaria recutita (L.) in the treatment of oral mucositis. Sci. World J. 2018:4392184. doi: 10.1155/2018/ 4392184

Gou, H., Gu, L. Y., Shang, B. Z., Xiong, Y., and Wang, C. (2016). Protective effect of bu-zhong-yi-qi decoction, the water extract of Chinese traditional herbal medicine, on 5-fluorouracil-induced intestinal mucositis in mice. Hum. Exp. Toxicol. 35, 1243-1251. doi: 10.1177/0960327115627686

Guan, H. Y., Li, P. F., Wang, X. M., Yue, J. J., He, Y., Luo, X. M., et al. (2017). Shengjiang Xiexin decoction alters pharmacokinetics of irinotecan by regulating metabolic enzymes and transporters: a multi-target therapy for alleviating the gastrointestinal toxicity. Front. Pharmacol. 8:769. doi: 10.3389/fphar.2017.00769

Han, X., Xue, X., Zhao, Y., Li, Y., Liu, W., Zhang, J., et al. (2017a). Rutin-enriched extract from Coriandrum sativum L. ameliorates ionizing radiation-induced hematopoietic injury. Int. J. Mol. Sci. 18:E942. doi: 10.3390/ijms18050942

Han, X., Zhang, J., Xue, X., Zhao, Y., Lu, L., Cui, M., et al. (2017b). Theaflavin ameliorates ionizing radiation-induced hematopoietic injury via the NRF2 pathway. Free Radic. Biol. Med. 113, 59-70. doi: 10.1016/j.freeradbiomed.2017.09.014

Hao, W., Liu, S., Qin, Y., Sun, C., Chen, L., Wu, C., et al. (2017). Cardioprotective effect of Platycodon grandiflorum in patients with early breast cancer receiving anthracycline-based chemotherapy: study protocol for a randomized controlled trial. Trials 18:386. doi: 10.1186/s13063-017-2140-Z

Hasona, N., and Morsi, A. (2018). Grape seed extract alleviates dexamethasoneinduced hyperlipidemia, lipid peroxidation, and hematological alteration in rats. Indian J. Clin. Biochem. doi: 10.1007/s12291-018-0736-Z

Hatcher, H., Planalp, R., Cho, J., Torti, F. M., and Torti, S. V. (2008). Curcumin: from ancient medicine to current clinical trials. Cell. Mol. Life Sci. 65, 1631-1652. doi: 10.1007/s00018-008-7452-4

He, H., Luo, Y., Qiao, Y., Zhang, Z., Yin, D., Yao, J., et al. (2018). Curcumin attenuates doxorubicin-induced cardiotoxicity via suppressing oxidative stress and preventing mitochondrial dysfunction mediated by 14-3-3gamma. Food Funct. 9, 4404-4418. doi: 10.1039/C8FO00466H

Heidari, Z., Salehzadeh, A., Sadat Shandiz, S. A., and Tajdoost, S. (2018). Anti-cancer and anti-oxidant properties of ethanolic leaf extract of Thymus vulgaris and its bio-functionalized silver nanoparticles. 3 Biotech 8:177. doi: $10.1007 /$ s13205-018-1199-x

Hitomi, S., Ono, K., Terawaki, K., Matsumoto, C., Mizuno, K., Yamaguchi, K., et al. (2017). [6]-gingerol and [6]-shogaol, active ingredients of the traditional Japanese medicine hangeshashinto, relief oral ulcerative mucositisinduced pain via action on $\mathrm{Na}(+)$ channels. Pharmacol. Res. 117, 288-302. doi: 10.1016/j.phrs.2016.12.026

Hong, J., Chen, X., Huang, J., Li, C., Zhong, L., Chen, L., et al. (2017). Danggui Buxue decoction, a classical formula of traditional Chinese medicine, fails to prevent myelosuppression in breast cancer patients treated with adjuvant chemotherapy: a prospective study. Integr. Cancer Ther. 16, 406-413. doi: $10.1177 / 1534735416675952$

Hoshino, N., Ganeko, R., Hida, K., and Sakai, Y. (2018). Goshajinkigan for reducing chemotherapy-induced peripheral neuropathy: a systematic review and meta-analysis. Int. J. Clin. Oncol. 23, 434-442. doi: $10.1007 /$ s10147-017-1229-4

Hosny Mansour, H., and Farouk Hafez, H. (2012). Protective effect of Withania somnifera against radiation-induced hepatotoxicity in rats. Ecotoxicol. Environ. Saf. 80, 14-19. doi: 10.1016/j.ecoenv.2012.02.003

Hosokawa, A., Ogawa, K., Ando, T., Suzuki, N., Ueda, A., Kajiura, S., et al. (2012). Preventive effect of traditional Japanese medicine on neurotoxicity of FOLFOX for metastatic colorectal cancer: a multicenter retrospective study. Anticancer Res. 32, 2545-2550. doi: 10.1016/s1359-6349(09)70696-2

Hosseini, A., and Sahebkar, A. (2017). Reversal of doxorubicin-induced cardiotoxicity by using phytotherapy: A review. J. Pharmacopuncture 20, 243-256. doi: 10.3831/KPI.2017.20.030

Hou, B., Liu, R., Qin, Z., Luo, D., Wang, Q., and Huang, S. (2017). Oral Chinese herbal medicine as an adjuvant treatment for chemotherapy, or radiotherapy, induced myelosuppression: a systematic review and metaAnalysis of randomized controlled trials. Evid. Based Complement. Alternat. Med. 2017:3432750. doi: 10.1155/2017/3432750

Ito, T., Urushima, H., Sakaue, M., Yukawa, S., Honda, H., Hirai, K., et al. (2014). Reduction of adverse effects by a mushroom product, active hexose correlated compound (AHCC) in patients with advanced cancer during chemotherapy-the significance of the levels of HHV-6 DNA in saliva as a surrogate biomarker during chemotherapy. Nutr. Cancer 66, 377-382. doi: 10.1080/01635581.2014.884232

Javadzadeh Bolouri, A., Pakfetrat, A., Tonkaboni, A., Aledavood, S. A., Fathi Najafi, M., Delavarian, Z., et al. (2015). Preventing and therapeutic effect of propolis in radiotherapy induced mucositis of head and neck cancers: a triple-blind, randomized, placebo-controlled trial. Iran J. Cancer Prev. 8:e4019. doi: $10.17795 /$ ijcp-4019

Kamide, D., Yamashita, T., Araki, K., Tomifuji, M., and Shiotani, A. (2017). Hangeshashinto (TJ-14) prevents radiation-induced mucositis by suppressing cyclooxygenase-2 expression and chemotaxis of inflammatory cells. Clin. Transl. Oncol. 19, 1329-1336. doi: 10.1007/s12094-017-1672-8

Karioti, A., Hadjipavlou-Litina, D., Mensah, M. L., Fleischer, T. C., and Skaltsa, H. (2004). Composition and antioxidant activity of the essential oils of Xylopia aethiopica (Dun) A. Rich. (Annonaceae) leaves, stem bark, root bark, and fresh and dried fruits, growing in Ghana. J. Agric. Food Chem. 52, 8094-8098. doi: 10.1021/jf040150j

Karuppagounder, V., Arumugam, S., Thandavarayan, R. A., Pitchaimani, V., Sreedhar, R., Afrin, R., et al. (2015). Naringenin ameliorates daunorubicin induced nephrotoxicity by mitigating AT1R, ERK1/2NFkappaB p65 mediated inflammation. Int. Immunopharmacol. 28, 154-159. doi: 10.1016/j.intimp.2015.05.050

Katiyar, S. K., Pal, H. C., and Prasad, R. (2017). Dietary proanthocyanidins prevent ultraviolet radiation-induced non-melanoma skin cancer through enhanced repair of damaged DNA-dependent activation of immune sensitivity. Semin. Cancer Biol. 46, 138-145. doi: 10.1016/j.semcancer.2017. 04.003

Kato, S., Hayashi, S., Kitahara, Y., Nagasawa, K., Aono, H., Shibata, J., et al. (2015). Saireito (TJ-114), a Japanese traditional herbal medicine, reduces 5 -fluorouracil-induced intestinal mucositis in mice by inhibiting cytokine-mediated apoptosis in intestinal crypt cells. PLoS ONE 10:e0116213. doi: 10.1371/journal.pone.0116213

Kato, S., Saito, A., Matsuda, N., Suzuki, H., Ujiie, M., Sato, S., et al. (2017). Management of afatinib-induced stomatitis. Mol. Clin. Oncol. 6, 603-605. doi: $10.3892 /$ mco.2017.1184

Kim, H. S., Kim, M. K., Lee, M., Kwon, B. S., Suh, D. H., and Song, Y. S. (2017). Effect of red ginseng on genotoxicity and health-related quality of life after adjuvant chemotherapy in patients with epithelial ovarian cancer: a randomized, double blind, placebo-controlled trial. Nutrients 9:E772. doi: 10.3390/nu9070772

Kim, J. S., Han, N. K., Kim, S. H., and Lee, H. J. (2017). Silibinin attenuates radiation-induced intestinal fibrosis and reverses epithelial-tomesenchymal transition. Oncotarget 8, 69386-69397. doi: 10.18632/oncotarget. 20624

Ko, J. W., Lee, I. C., Park, S. H., Moon, C., Kang, S. S., Kim, S. H., et al. (2014). Protective effects of pine bark extract against cisplatin-induced hepatotoxicity and oxidative stress in rats. Lab. Anim. Res. 30, 174-180. doi: 10.5625/lar.2014.30.4.174 
Konmun, J., Danwilai, K., Ngamphaiboon, N., Sripanidkulchai, B., Sookprasert, A., and Subongkot, S. (2017). A phase II randomized double-blind placebocontrolled study of 6-gingerol as an anti-emetic in solid tumor patients receiving moderately to highly emetogenic chemotherapy. Med. Oncol. 34:69. doi: $10.1007 / \mathrm{s} 12032-017-0931-4$

Kooshyar, M. M., Mozafari, P. M., Amirchaghmaghi, M., Pakfetrat, A., Karoos, P., Mohasel, M. R., et al. (2017). A randomized placebo- controlled double blind clinical trial of quercetin in the prevention and treatment of chemotherapy-induced oral mucositis. J. Clin. Diagn. Res. 11, ZC46-ZC50. doi: 10.7860/JCDR/2017/23975.9571

Kumari, K. K., and Setty, O. H. (2012). Protective effect of Phyllanthus fraternus against mitochondrial dysfunction induced by co-administration of cisplatin and cyclophosphamide. J. Bioenerg. Biomembr. 44, 179-188. doi: 10.1007/s10863-012-9423-6

Kummar, S., Copur, M. S., Rose, M., Wadler, S., Stephenson, J., O'rourke, M., et al. (2011). A phase I study of the chinese herbal medicine PHY906 as a modulator of irinotecan-based chemotherapy in patients with advanced colorectal cancer. Clin. Colorectal. Cancer 10, 85-96. doi: 10.1016/j.clcc.2011.03.003

Kuriyama, A., and Endo, K. (2018). Goshajinkigan for prevention of chemotherapy-induced peripheral neuropathy: a systematic review and meta-analysis. Support. Care Cancer 26, 1051-1059. doi: 10.1007/s00520-017-4028-6

Lam, W., Jiang, Z., Guan, F., Hu, R., Liu, S. H., Chu, E., et al. (2014). The number of intestinal bacteria is not critical for the enhancement of antitumor activity and reduction of intestinal toxicity of irinotecan by the Chinese herbal medicine PHY906 (KD018). BMC Complement. Altern. Med. 14:490. doi: $10.1186 / 1472-6882-14-490$

Lee, G., and Kim, S. K. (2016). Therapeutic effects of phytochemicals and medicinal herbs on chemotherapy-induced peripheral neuropathy. Molecules 21:E1252. doi: $10.3390 /$ molecules 21091252

Lee, I. C., Ko, J. W., Park, S. H., Shin, N. R., Shin, I. S., Kim, Y. B., et al. (2017). Ameliorative effects of pine bark extract on cisplatin-induced acute kidney injury in rats. Ren. Fail. 39, 363-371. doi: 10.1080/0886022X.2017.1282871

Lee, W. J., Kim, H. W., Lee, H. Y., and Son, C. G. (2015). Systematic review on herb-induced liver injury in Korea. Food Chem. Toxicol. 84, 47-54. doi: 10.1016/j.fct.2015.06.004

Leyva-Lopez, N., Gutierrez-Grijalva, E. P., Vazquez-Olivo, G., and Heredia, J. B. (2017). Essential oils of oregano: biological activity beyond their antimicrobial properties. Molecules 22:E989. doi: 10.3390/molecules22060989

Li, B., Wang, Z., Fang, J. J., Xu, C. Y., and Chen, W. X. (2007). Evaluation of prognostic markers in severe drug-induced liver disease. World J. Gastroenterol. 13, 628-632. doi: 10.3748/wjg.v13.i4.628

Li, D. W., Sun, J. Y., Wang, K., Zhang, S., Hou, Y. J., Yang, M. F., et al. (2015). Attenuation of cisplatin-induced neurotoxicity by Cyanidin, a natural inhibitor of ROS-mediated apoptosis in PC12 Cells. Cell. Mol. Neurobiol. 35, 995-1001. doi: 10.1007/s10571-015-0194-6

Li, Q., Chen, G., Chen, H., Zhang, W., Ding, Y., Yu, P., et al. (2018). Seenriched G. frondosa polysaccharide protects against immunosuppression in cyclophosphamide-induced mice via MAPKs signal transduction pathway. Carbohydr. Polym. 196, 445-456. doi: 10.1016/j.carbpol.2018. 05.046

Li, Y., Ye, Z., Lai, W., Rao, J., Huang, W., Zhang, X., et al. (2017). Activation of Sirtuin 3 by silybin attenuates mitochondrial dysfunction in cisplatin-induced acute kidney injury. Front. Pharmacol. 8:178. doi: 10.3389/fphar.2017.00178

Lin, H. M., Lin, L. F., Xia, Z. Z., Mao, Y., Liu, J., Xu, L. Y., et al. (2017). Neuroprotective effects and UPLC-Q-TOF/MS-based active components identification of external applied a novel Wen-Luo-Tong microemulsion. Artif. Cells Nanomed. Biotechnol. doi: 10.1080/21691401.2017.1397002. [Epub ahead of print].

Liu, Y., Tan, D., Shi, L., Liu, X., Zhang, Y., Tong, C., et al. (2015). Blueberry anthocyanins-enriched extracts attenuate cyclophosphamide-induced cardiac injury. PLoS ONE 10:e0127813. doi: 10.1145/2818302

Lo, L. C., Chen, C. Y., Chen, S. T., Chen, H. C., Lee, T. C., and Chang, C. S. (2012). Therapeutic efficacy of traditional Chinese medicine, Shen-Mai San, in cancer patients undergoing chemotherapy or radiotherapy: study protocol for a randomized, double-blind, placebo-controlled trial. Trials 13:232. doi: $10.1186 / 1745-6215-13-232$
Ma, Z. N., Liu, Z., Wang, Z., Ren, S., Tang, S., Wang, Y. P., et al. (2017). Supplementation of American ginseng berry extract mitigated cisplatinevoked nephrotoxicity by suppressing ROS-mediated activation of MAPK and NF-kappaB signaling pathways. Food Chem. Toxicol. 110, 62-73. doi: 10.1016/j.fct.2017.10.006

Mahendran, V. J., Stringer, A. M., Semple, S. J., Song, Y., and Garg, S. (2018). Advances in the use of anti-inflammatory agents to manage chemotherapyinduced oral and gastrointestinal mucositis. Curr. Pharm. Des. 24, 1518-1532. doi: $10.2174 / 1381612824666180409093918$

Mahmoodnia, L., Mohammadi, K., and Masumi, R. (2017). Ameliorative effect of lycopene effect on cisplatin-induced nephropathy in patient. J. Nephropathol. 6, 144-149. doi: 10.15171/jnp.2017.25

Mannelli, L. D., Pacini, A., Micheli, L., Femia, A. P., Maresca, M., Zanardelli, M., et al. (2017). Astragali radix: could it be an adjuvant for oxaliplatin-induced neuropathy? Sci. Rep. 7:42021. doi: 10.1038/srep42021

Mannelli, L. D. C., Zanardelli, M., Bartolucci, G., Karioti, A., Bilia, A. R., Vannacci, A., et al. (2015). In vitro evidence for the use of Astragali Radix extracts as adjuvant against oxaliplatin-induced neurotoxicity. Planta. Medica. 81, 1045-1055. doi: 10.1055/s-0035-1546117

Mansour, S. Z., Moawed, F. S. M., and Elmarkaby, S. M. (2017). Protective effect of 5, 7-dihydroxyflavone on brain of rats exposed to acrylamide or gamma-radiation. J. Photochem. Photobiol. B. 175, 149-155. doi: 10.1016/j.jphotobiol.2017.08.034

Mansouri, P., Haghighi, M., Beheshtipour, N., and Ramzi, M. (2016). The effect of aloe vera solution on chemotherapy-induced stomatitis in clients with lymphoma and leukemia: a randomized controlled clinical trial. Int. J. Community Based Nurs. Midwifery. 4, 119-126.

Matsumoto, C., Sekine-Suzuki, E., Nyui, M., Ueno, M., Nakanishi, I., Omiya, Y., et al. (2015). Analysis of the antioxidative function of the radioprotective Japanese traditional (Kampo) medicine, hangeshashinto, in an aqueous phase. J. Radiat. Res. 56, 669-677. doi: 10.1093/jrr/rrv023

Mcguire, S. (2016). World Cancer Report 2014. Geneva, Switzerland: World Health Organization, international agency for research on cancer, WHO Press, 2015. Adv. Nutr. 7, 418-419. doi: 10.3945/an.116.012211

Metri, K., Bhargav, H., Chowdhury, P., and Koka, P. S. (2013). Ayurveda for chemo-radiotherapy induced side effects in cancer patients. J. Stem Cells. 8, 115-129. doi: jsc.2014.8.2.115

Meydan, D., Gursel, B., Bilgici, B., Can, B., and Ozbek, N. (2011). Protective effect of lycopene against radiation-induced hepatic toxicity in rats. J. Int. Med. Res. 39, 1239-1252. doi: 10.1177/147323001103900412

Mirian, M., Behrooeian, M., Ghanadian, M., Dana, N., and Sadeghi-Aliabadi, H. (2015). Cytotoxicity and antiangiogenic effects of Rhus coriaria, Pistacia vera and Pistacia khinjuk oleoresin methanol extracts. Res. Pharm. Sci. 10, 233-240.

Mohamad, R. H., El-Bastawesy, A. M., Zekry, Z. K., Al-Mehdar, H. A., AlSaid, M. G., Aly, S. S., et al. (2009). The role of Curcuma longa against doxorubicin (adriamycin)-induced toxicity in rats. J. Med. Food 12, 394-402. doi: 10.1089/jmf.2007.0715

Najaf Najafi, M., Salehi, M., Ghazanfarpour, M., Hoseini, Z. S., and KhademRezaiyan, M. (2018). The association between green tea consumption and breast cancer risk: a systematic review and meta-analysis. Phytother. Res. 32, 1855-1864. doi: 10.1002/ptr.6124

Nambiar, D. K., Rajamani, P., Deep, G., Jain, A. K., Agarwal, R., and Singh, R. P. (2015). Silibinin preferentially radiosensitizes prostate cancer by inhibiting DNA repair signaling. Mol. Cancer Ther. 14, 2722-2734. doi: 10.1158/1535-7163.MCT-15-0348

Nawaz, N. U. A., Saeed, M., Rauf, K., Usman, M., Arif, M., Ullah, Z., et al. (2018). Antinociceptive effectiveness of Tithonia tubaeformis in a vincristine model of chemotherapy-induced painful neuropathy in mice. Biomed. Pharmacother. 103, 1043-1051. doi: 10.1016/j.biopha.2018.04.115

Nazari, M., Taghizadeh, A., Bazzaz, M. M., Rakhshandeh, H., and Shokri, S. (2017). Effect of persian medicine remedy on chemotherapy induced nausea and vomiting in breast cancer: a double blind, randomized, crossover clinical trial. Electr. Phys. 9, 3535-3543. doi: 10.19082/3535

Nishikawa, K., Aoyama, T., Oba, M. S., Yoshikawa, T., Matsuda, C., Munemoto, Y., et al. (2018). The clinical impact of Hangeshashinto (TJ-14) in the treatment of chemotherapy-induced oral mucositis in gastric cancer and colorectal cancer: Analyses of pooled data from two phase II randomized 
clinical trials (HANGESHA-G and HANGESHA-C). J. Cancer 9, 1725-1730. doi: 10.7150/jca.24733

Ochwang'i, D. O., Kimwele, C. N., Oduma, J. A., Gathumbi, P. K., Mbaria, J. M., and Kiama, S. G. (2014). Medicinal plants used in treatment and management of cancer in Kakamega County, Kenya. J. Ethnopharmacol. 151, 1040-1055. doi: 10.1016/j.jep.2013.11.051

Ojha, S., Venkataraman, B., Kurdi, A., Mahgoub, E., Sadek, B., and Rajesh, M. (2016). Plant-derived agents for counteracting cisplatininduced nephrotoxicity. Oxid. Med. Cell Longev. 2016:4320374. doi: $10.1155 / 2016 / 4320374$

Oki, E., Emi, Y., Kojima, H., Higashijima, J., Kato, T., Miyake, Y., et al. (2015). Preventive effect of Goshajinkigan on peripheral neurotoxicity of FOLFOX therapy (GENIUS trial): a placebo-controlled, double-blind, randomized phase III study. Int. J. Clin. Oncol. 20, 767-775. doi: 10.1007/s10147-015-0784-9

Olaku, O. O., Ojukwu, M. O., Zia, F. Z., and White, J. D. (2015). The role of grape seed extract in the treatment of chemo/radiotherapy induced toxicity: a systematic review of preclinical studies. Nutr. Cancer 67, 730-740. doi: 10.1080/01635581.2015.1029639

Osama, H., Abdullah, A., Gamal, B., Emad, D., Sayed, D., Hussein, E., et al. (2017). Effect of honey and royal jelly against cisplatin-induced nephrotoxicity in patients with cancer. J. Am. Coll. Nutr. 36, 342-346. doi: 10.1080/07315724.2017.1292157

Ozaslan, M., Didem Karagoz, I., Kalender, M. E., Kilic, I. H., Sari, I., and Karagoz, A. (2007). In vivo antitumoral effect of Plantago major L. extract on Balb/C mouse with Ehrlich ascites tumor. Am. J. Chin. Med. 35, 841-851. doi: 10.1142/S0192415X07005314

Ozyurt, H., Cevik, O., Ozgen, Z., Ozden, A. S., Cadirci, S., Elmas, M. A., et al. (2014). Quercetin protects radiation-induced DNA damage and apoptosis in kidney and bladder tissues of rats. Free Radic. Res. 48, 1247-1255. doi: $10.3109 / 10715762.2014 .945925$

Palipoch, S., Punsawad, C., Koomhin, P., and Suwannalert, P. (2014). Hepatoprotective effect of curcumin and alpha-tocopherol against cisplatin-induced oxidative stress. BMC Complement. Altern. Med. 14:111. doi: $10.1186 / 1472-6882-14-111$

Panahi, Y., Saadat, A., Shadboorestan, A., and Ahmadi, A. (2016). An updated review of natural products intended to prevent or treat oral mucositis in patients undergoing radio-chemotherapy. Curr. Pharm. Biotechnol. 17, 949-961. doi: 10.2174/13892010176661608080 94008

Patil, K., Guledgud, M. V., Kulkarni, P. K., Keshari, D., and Tayal, S. (2015). Use of curcumin mouthrinse in radio-chemotherapy induced oral mucositis patients: a pilot study. J. Clin. Diagn. Res. 9, ZC59-ZC62. doi: $10.7860 / J C D R / 2015 / 13034.6345$

Peterson, C. T., Sharma, V., Uchitel, S., Denniston, K., Chopra, D., Mills, P. J., et al. (2018). Prebiotic potential of herbal medicines used in digestive health and disease. J. Altern. Complement. Med. 24, 656-665. doi: 10.1089/acm.2017.0422

Prack Mc Cormick, B., Langle, Y., Belgorosky, D., Vanzulli, S., Balarino, N., Sandes, E., et al. (2018). Flavonoid silybin improves the response to radiotherapy in invasive bladder cancer. J. Cell. Biochem. 119, 5402-5412. doi: $10.1002 / j \mathrm{cb} .26693$

Pradeep, K., Ko, K. C., Choi, M. H., Kang, J. A., Chung, Y. J., and Park, S. H. (2012). Protective effect of hesperidin, a citrus flavanoglycone, against gammaradiation-induced tissue damage in Sprague-Dawley rats. J. Med. Food 15, 419-427. doi: 10.1089/jmf.2011.1737

Quintanilha, J. C. F., Visacri, M. B., Sousa, V. M., Bastos, L. B., Vaz, C. O., Guarnieri, J. P. O., et al. (2018). Cisplatin-induced human peripheral blood mononuclear cells' oxidative stress and nephrotoxicity in head and neck cancer patients: the influence of hydrogen peroxide. Mol. Cell. Biochem. 440, 139-145. doi: 10.1007/s11010-017-3162-2

Radwan, R. R., and Mohamed, H. A. (2018). Nigella sativa oil modulates the therapeutic efficacy of mesenchymal stem cells against liver injury in irradiated rats. J. Photochem. Photobiol. B 178, 447-456. doi: 10.1016/j.jphotobiol.2017.11.037

Ramkumar, M., Rajasankar, S., Gobi, V. V., Dhanalakshmi, C., Manivasagam, T., Justin Thenmozhi, A., et al. (2017). Neuroprotective effect of demethoxycurcumin, a natural derivative of curcumin on rotenone induced neurotoxicity in SH-SY 5Y Neuroblastoma cells. BMC Complement. Altern. Med. 17:217. doi: 10.1186/s12906-017-1720-5
Rashid, S., Nafees, S., Siddiqi, A., Vafa, A., Afzal, S. M., Parveen, R., et al. (2017). Partial protection by 18beta Glycrrhetinic acid against cisplatin induced oxidative intestinal damage in wistar rats: possible role of NFkB and caspases. Pharmacol. Rep. 69, 1007-1013. doi: 10.1016/j.pharep.2017.02.013

Rezaee, R., Momtazi, A. A., Monemi, A., and Sahebkar, A. (2017). Curcumin: a potentially powerful tool to reverse cisplatin-induced toxicity. Pharmacol Res. 117, 218-227. doi: 10.1016/j.phrs.2016.12.037

Ryan, J. L., Heckler, C. E., Roscoe, J. A., Dakhil, S. R., Kirshner, J., Flynn, P. J., et al. (2012). Ginger (Zingiber officinale) reduces acute chemotherapyinduced nausea: a URCC CCOP study of 576 patients. Support. Care Cancer 20, 1479-1489. doi: 10.1007/s00520-011-1236-3

Saberi, H., Keshavarzi, B., Shirpoor, A., Gharalari, F. H., and Rasmi, Y. (2017). Rescue effects of ginger extract on dose dependent radiation-induced histological and biochemical changes in the kidneys of male Wistar rats. Biomed. Pharmacother. 94, 569-576. doi: 10.1016/j.biopha.2017.07.128

Sahebnasagh, A., Ghasemi, A., Akbari, J., Alipour, A., Lashkardoost, H., Ala, S., et al. (2017). Successful treatment of acute radiation proctitis with Aloe Vera: a preliminary randomized controlled clinical trial. J. Altern. Complement. Med. 23, 858-865. doi: 10.1089/acm.2017.0047

Sahin, K., Orhan, C., Tuzcu, M., Muqbil, I., Sahin, N., Gencoglu, H., et al. (2014). Comparative in vivo evaluations of curcumin and its analog difluorinated curcumin against cisplatin-induced nephrotoxicity. Biol. Trace. Elem. Res. 157, 156-163. doi: 10.1007/s12011-014-9886-x

Sailo, B. L., Banik, K., Padmavathi, G., Javadi, M., Bordoloi, D., and Kunnumakkara, A. B. (2018). Tocotrienols: the promising analogues of vitamin E for cancer therapeutics. Pharmacol. Res. 130, 259-272. doi: $10.1016 /$ j.phrs.2018.02.017

Sandeep, D., and Nair, C. K. (2012). Protection from lethal and sub-lethal whole body exposures of mice to gamma-radiation by Acorus calamus L.: studies on tissue antioxidant status and cellular DNA damage. Exp. Toxicol. Pathol. 64, 57-64. doi: 10.1016/j.etp.2010.06.006

Sanders, K., Moran, Z., Shi, Z., Paul, R., and Greenlee, H. (2016). Natural products for cancer prevention: clinical update 2016. Semin. Oncol. Nurs. 32, 215-240. doi: 10.1016/j.soncn.2016.06.001

Sano, A. (2017). Safety assessment of 4-week oral intake of proanthocyanidinrich grape seed extract in healthy subjects. Food Chem. Toxicol. 108, 519-523. doi: 10.1016/j.fct.2016.11.021

Schloss, J., Colosimo, M., and Vitetta, L. (2017). Herbal medicines and chemotherapy induced peripheral neuropathy (CIPN): A critical literature review. Crit. Rev. Food Sci. Nutr. 57, 1107-1118. doi: 10.1080/10408398.2014.889081

Segat, G. C., Manjavachi, M. N., Matias, D. O., Passos, G. F., Freitas, C. S., Costa, R., et al. (2017). Antiallodynic effect of beta-caryophyllene on paclitaxelinduced peripheral neuropathy in mice. Neuropharmacology 125, 207-219. doi: 10.1016/j.neuropharm.2017.07.015

Seo, C. S., Jeong, S. J., Yoo, S. R., Lee, N. R., and Shin, H. K. (2016). Quantitative analysis and in vitro anti-inflammatory effects of gallic acid, ellagic acid, and quercetin from Radix Sanguisorbae. Pharmacogn. Mag. 12, 104-108. doi: 10.4103/0973-1296.177908

Serban, D. E. (2014). Gastrointestinal cancers: influence of gut microbiota, probiotics and prebiotics. Cancer Lett. 345, 258-270. doi: 10.1016/j.canlet.2013.08.013

Seyyedi, S. A., Sanatkhani, M., Pakfetrat, A., and Olyaee, P. (2014). The therapeutic effects of chamomilla tincture mouthwash on oral aphthae: a randomized clinical trial. J. Clin. Exp. Dent. 6, e535-e538. doi: 10.4317/jced.51472

Shahid, F., Farooqui, Z., Abidi, S., Parwez, I., and Khan, F. (2017a). Oral administration of thymoquinone mitigates the effect of cisplatin on brush border membrane enzymes, energy metabolism and antioxidant system in rat intestine. Biomed. Pharmacother. 94, 1111-1120. doi: 10.1016/j.biopha.2017.08.044

Shahid, F., Farooqui, Z., Rizwan, S., Abidi, S., Parwez, I., and Khan, F. (2017b). Oral administration of Nigella sativa oil ameliorates the effect of cisplatin on brush border membrane enzymes, carbohydrate metabolism and antioxidant system in rat intestine. Exp. Toxicol. Pathol. 69, 299-306. doi: 10.1016/j.etp.2017. 02.001

Shapiro, C. L. (2016). Highlights of recent findings on quality-of-life management for patients with cancer and their survivors. JAMA Oncol. 2, 1401-1402. doi: $10.1001 /$ jamaoncol.2016.3620 
Sharma, S., Joshi, A., and Hemalatha, S. (2017). Protective effect of Withania coagulans fruit extract on cisplatin-induced nephrotoxicity in rats. Pharmacognosy Res. 9, 354-361. doi: 10.4103/pr.pr_1_17

Shi, C. J., Wen, X. S., Gao, H. F., Liu, Z. H., Xu, X. K., Li, L. F., et al. (2016). Steamed root of Rehmannia glutinosa Libosch (Plantaginaceae) alleviates methotrexate-induced intestinal mucositis in rats. J. Ethnopharmacol. 183, 143-150. doi: 10.1016/j.jep.2016.02.035

Shi, H., Chang, Y., Gao, Y., Wang, X., Chen, X., Wang, Y., et al. (2017). Dietary fucoidan of Acaudina molpadioides alters gut microbiota and mitigates intestinal mucosal injury induced by cyclophosphamide. Food Funct. 8, 3383-3393. doi: 10.1039/C7FO00932A

Soliman, A. F., Anees, L. M., and Ibrahim, D. M. (2018). Cardioprotective effect of zingerone against oxidative stress, inflammation, and apoptosis induced by cisplatin or gamma radiation in rats. Naunyn Schmiedebergs Arch. Pharmacol. doi: 10.1007/s00210-018-1506-4

Soliman, A. M., Desouky, S., Marzouk, M., and Sayed, A. A. (2016). Origanum majorana attenuates nephrotoxicity of cisplatin anticancer drug through ameliorating oxidative stress. Nutrients 8:264. doi: 10.3390/nu8050264

Spagnuolo, C., Russo, G. L., Orhan, I. E., Habtemariam, S., Daglia, M., Sureda, A., et al. (2015). Genistein and cancer: current status, challenges, and future directions. Adv. Nutr. 6, 408-419. doi: 10.3945/an.114.008052

Su, Z., Ye, J., and Pang, H. (2015). Effect of Qiluxiaobai decoction on glomerular sclerosis in adriamycin-induced nephropathic rats. Zhong Nan Da Xue Xue Bao Yi Xue Ban 40, 83-89. doi: 10.11817/j.issn.1672-7347.2015.01.014

Sun, C., Yang, J., Pan, L., Guo, N., Li, B., Yao, J., et al. (2018). Improvement of icaritin on hematopoietic function in cyclophosphamide-induced myelosuppression mice. Immunopharmacol. Immunotoxicol. 40, 25-34. doi: 10.1080/08923973.2017.1392564

Sun, M., Ye, Y., Xiao, L., Duan, X., Zhang, Y., and Zhang, H. (2017). Anticancer effects of ginsenoside Rg3 (Review). Int. J. Mol. Med. 39, 507-518. doi: 10.3892/ijmm.2017.2857

Sun, X., Zhao, Y. N., Qian, S., Gao, R. L., Yin, L. M., Wang, L. P., et al. (2018). Ginseng-derived panaxadiol saponins promote hematopoiesis recovery in cyclophosphamide-induced myelosuppressive mice: Potential novel rreatment of chemotherapy-induced cytopenias. Chin. J. Integr. Med. 24, 200-206. doi: 10.1007/s11655-017-2754-8

Takano, H., Momota, Y., Kani, K., Aota, K., Yamamura, Y., Yamanoi, T., et al. (2015). gamma-Tocotrienol prevents 5-FU-induced reactive oxygen species production in human oral keratinocytes through the stabilization of 5-FU-induced activation of Nrf2. Int. J. Oncol. 46, 1453-1460. doi: $10.3892 /$ ijo. 2015.2849

Tan, C., Qian, X., Ge, Y., Yang, B., Wang, F., Guan, Z., et al. (2017). Oroxylin a could be a promising radiosensitizer for esophageal squamous cell carcinoma by inducing G2/M arrest and activating apoptosis. Pathol. Oncol. Res. 23, 323-328. doi: 10.1007/s12253-016-0106-1

Tatsadjieu, L. N., Essia Ngang, J. J., Ngassoum, M. B., and Etoa, F. X. (2003). Antibacterial and antifungal activity of Xylopia aethiopica, Monodora myristica, Zanthoxylum xanthoxyloi; des and Zanthoxylum leprieurii from Cameroon. Fitoterapia 74, 469-472. doi: 10.1016/S0367-326X(03)00067-4

Tomazevic, T., and Jazbec, J. (2013). A double blind randomised placebo controlled study of propolis (bee glue) effectiveness in the treatment of severe oral mucositis in chemotherapy treated children. Complement. Ther. Med. 21, 306-312. doi: 10.1016/j.ctim.2013.04.002

Turcotte, L. M., Liu, Q., Yasui, Y., Arnold, M. A., Hammond, S., Howell, R. M., et al. (2017). Temporal trends in rreatment and subsequent neoplasm risk Among 5-Year survivors of childhood cancer, 1970-2015. JAMA 317, 814-824. doi: 10.1001/jama.2017.0693

Ugur, S., Ulu, R., Dogukan, A., Gurel, A., Yigit, I. P., Gozel, N., et al. (2015). The renoprotective effect of curcumin in cisplatin-induced nephrotoxicity. Ren. Fail. 37, 332-336. doi: 10.3109/0886022X.2014.986005

Ullah, I., Subhan, F., Lu, Z., Chan, S. W., and Rudd, J. A. (2017). Action of Bacopa monnieri to antagonize cisplatin-induced emesis in Suncus murinus (house musk shrew). J. Pharmacol. Sci. 133, 232-239. doi: 10.1016/j.jphs.2017.03.001

Varghese, M. V., Abhilash, M., Alex, M., Paul, M. V. S., Prathapan, A., Raghu, K. G., et al. (2017). Attenuation of arsenic trioxide induced cardiotoxicity through flaxseed oil in experimental rats. Redox Rep. 22, 346-352. doi: 10.1080/13510002.2017.1289313
Velaga, M. K., Yallapragada, P. R., Williams, D., Rajanna, S., and Bettaiya, R. (2014). Hydroalcoholic seed extract of Coriandrum sativum (Coriander) alleviates lead-induced oxidative stress in different regions of rat brain. Biol. Trace Elem. Res. 159, 351-363. doi: 10.1007/s12011-014-9989-4

Wan, Y. G., Che, X. Y., Sun, W., Huang, Y. R., Meng, X. J., Chen, H. L., et al. (2014). Low-dose of multi-glycoside of Tripterygium wilfordii Hook. f., a natural regulator of TGF-beta1/Smad signaling activity improves adriamycininduced glomerulosclerosis in vivo. J. Ethnopharmacol. 151, 1079-1089. doi: 10.1016/j.jep.2013.12.005

Wang, C., Li, J., Song, G. L., Niu, Q., Xu, S. Z., Feng, G. L., et al. (2017). Grape seed procyanidin extract reduces arsenic-induced renal inflammatory injury in male mice. Biomed. Environ. Sci. 30, 535-539. doi: 10.3967/bes2017.071

Wang, C. Z., Anderson, S., Du, W., He, T. C., and Yuan, C. S. (2016). Red ginseng and cancer treatment. Chin. J. Nat. Med. 14, 7-16. doi: 10.3724/SP.J.1009.2016.00007

Wang, J. Y., Lee, C. Y., Pan, P. J., Chang, W. C., Chiu, J. H., Chen, W. S., et al. (2014). Herb-induced autoimmune-like hepatitis in C57BL/6J mice. Liver Int. 34, 583-593. doi: 10.1111/liv.12266

Wang, L. F., Xu, Z. Y., Wang, Z. Q., Zhang, M., Yan, G. Y., Hou, A. J., et al. (2017). Clinical observation of Shuanghuang Shengbai Granule () on prevention and treatment of myelosuppression caused by chemotherapy in cancer patients. Chin. J. Integr. Med. 23, 105-109. doi: 10.1007/s11655-016-2503-4

Wang, L. J., Lu, J. Z., Cai, B. N., Li, M. W., and Qu, B. L. (2017). Effect of compound Zhuye Shigao Granule () on acute radiation-induced esophagitis in cancer patients: a randomized controlled trial. Chin. J. Integr. Med. 23, 98-104. doi: 10.1007/s11655-016-2652-5

Wang, X., Cui, D. N., Dai, X. M., Wang, J., Zhang, W., Zhang, Z. J., et al. (2017). HuangQin decoction attenuates CPT-11-induced gastrointestinal toxicity by regulating bile acids metabolism homeostasis. Front. Pharmacol. 8:156. doi: 10.3389/fphar.2017.00156

Wardill, H. R., and Tissing, W. J. E. (2017). Determining risk of severe gastrointestinal toxicity based on pretreatment gut microbial community in patients receiving cancer treatment: a new predictive strategy in the quest for personalized cancer medicine. Curr. Opin. Support. Palliat. Care 11, 125-132. doi: 10.1097/SPC.0000000000000265

Waseem, M., Pandey, P., Tomar, B., Raisuddin, S., and Parvez, S. (2014). Ameliorative action of curcumin in cisplatin-mediated hepatotoxicity: an in vivo study in Wistar rats. Arch. Med. Res. 45, 462-468. doi: 10.1016/j.arcmed.2014.07.006

Waseem, M., Parvez, S., and Tabassum, H. (2017). Mitochondria as the target for the modulatory effect of curcumin in oxaliplatin-induced toxicity in isolated rat liver mitochondria. Arch. Med. Res. 48, 55-63. doi: 10.1016/j.arcmed.2017.01.010

Wei, L., Dai, Y., Zhou, Y., He, Z., Yao, J., Zhao, L., et al. (2017). Oroxylin A activates PKM1/HNF4 alpha to induce hepatoma differentiation and block cancer progression. Cell Death Dis. 8:e2944. doi: 10.1038/cddis.2017.335

Westfall, S., Lomis, N., and Prakash, S. (2018). A novel polyphenolic prebiotic and probiotic formulation have synergistic effects on the gut microbiota influencing Drosophila melanogaster physiology. Artif. Cells Nanomed. Biotechnol. doi: 10.1080/21691401.2018.1458731. [Epub ahead of print].

Wu, B. Y., Liu, C. T., Chen, S. Y., and Tsai, M. Y. (2015). A case of chemotherapy-induced congestive heart failure successfully treated with Chinese herbal medicine. Complement. Ther. Med. 23, 251-256. doi: 10.1016/j.ctim.2015.01.006

Wu, R., Yao, P. A., Wang, H. L., Gao, Y., Yu, H. L., Wang, L., et al. (2018). Effect of fermented Cordyceps sinensis on doxorubicininduced cardiotoxicity in rats. Mol. Med. Rep. 18, 3229-3241. doi: 10.3892/mmr.2018.9310

Xu, J. L., Xia, R., Sun, Z. H., Sun, L., Min, X., Liu, C., et al. (2016). Effects of honey use on the management of radio/chemotherapy-induced mucositis: a meta-analysis of randomized controlled trials. Int. J. Oral. Maxillofac. Surg. 45, 1618-1625. doi: 10.1016/j.ijom.2016.04.023

Xue, X. L., Han, X. D., Li, Y., Chu, X. F., Miao, W. M., Zhang, J. L., et al. (2017). Astaxanthin attenuates total body irradiation-induced hematopoietic system injury in mice via inhibition of oxidative stress and apoptosis. Stem Cell Res. Ther. 8:7. doi: 10.1186/s13287-016-0464-3

Yang, X., Liu, T., Chen, B., Wang, F., Yang, Q., and Chen, X. (2017). Grape seed proanthocyanidins prevent irradiation-induced differentiation of human 
lung fibroblasts by ameliorating mitochondrial dysfunction. Sci. Rep. 7:62. doi: 10.1038/s41598-017-00108-9

Yao, J. M., Yu, L. J., Chen, Q., Chen, Z. Q., Wang, D. S., Qiu, X. J., et al. (2014). Comparison of ferulic acid content in radix angelicae sinensis, danggui-buxue-tang and danggui-sini-tang. Exp. Ther. Med. 7, 1364-1368. doi: 10.3892/etm.2014.1547

Yi, X., Zhu, J., Zhang, J., Gao, Y., Chen, Z., Lu, S., et al. (2018). Investigation of the reverse effect of Danhong injection on doxorubicin-induced cardiotoxicity in H9c2 cells: Insight by LC-MS based non-targeted metabolomic analysis. J. Pharm. Biomed. Anal. 152, 264-270. doi: 10.1016/j.jpba.2018. 02.012

Yildirim, N. C., Kandemir, F. M., Ceribasi, S., Ozkaraca, M., and Benzer, F. (2013). Pomegranate seed extract attenuates chemotherapy-induced liver damage in an experimental model of rabbits. Cell. Mol. Biol. 59, OL1842-OL1847. doi: $10.1170 / 218$

Yousef, M. I., Khalil, D., and Abdou, H. M. (2018). Neuro- and nephroprotective effect of grape seed proanthocyanidin extract against carboplatin and thalidomide through modulation of inflammation, tumor suppressor protein p53, neurotransmitters, oxidative stress and histology. Toxicol. Rep. 5, 568-578. doi: 10.1016/j.toxrep.2018.04.006

Yu, J., Gao, H., Wu, C., Xu, Q. M., Lu, J. J., and Chen, X. (2018a). Diethyl blechnic, a novel natural product isolated from Salvia miltiorrhiza Bunge, inhibits doxorubicin-induced apoptosis by inhibiting ROS and activating JNK1/2. Int. J. Mol. Sci. 19:E1809. doi: 10.3390/ijms19061809

Yu, J., Wang, C., Kong, Q., Wu, X., Lu, J. J., and Chen, X. (2018b). Recent progress in doxorubicin-induced cardiotoxicity and protective potential of natural products. Phytomedicine 40, 125-139. doi: 10.1016/j.phymed.2018.01.009

Zhang, J., Li, H., Lu, L., Yan, L., Yang, X., Shi, Z., et al. (2017). The Yiqi and Yangyin Formula ameliorates injury to the hematopoietic system induced by total body irradiation. J. Radiat. Res. 58, 1-7. doi: 10.1093/jrr/rrw056

Zhang, Y., Wang, X. Q., Liu, H., Liu, J., Hou, W., and Lin, H. S. (2018). A multicenter, large-sample, randomized clinical trial on improving the median survival time of advanced non-small cell lung cancer by combination of Ginseng Rg3 and chemotherapy. Zhonghua Zhong Liu Za Zhi 40, 295-299. doi: 10.3760/cma.j.issn.0253-3766.2018.04.011

Zhao, L., Tao, X., Qi, Y., Xu, L., Yin, L., and Peng, J. (2018). Protective effect of dioscin against doxorubicin-induced cardiotoxicity via adjusting microRNA-140-5p-mediated myocardial oxidative stress. Redox. Biol. 16, 189-198. doi: 10.1016/j.redox.2018.02.026
Zhao, L. M., Ji, X., Shan, B. E., Han, L. N., Pan, X. M., Peng, H., et al. (2010). The effects of ICA on the cell-immunosuppressive and bone-marrow-suppressive mice after chemotherapy. Xi Bao Yu Fen Zi Mian Yi Xue Za Zhi 26, 976-979.

Zhao, Q., Kretschmer, N., Bauer, R., and Efferth, T. (2015). Shikonin and its derivatives inhibit the epidermal growth factor receptor signaling and synergistically kill glioblastoma cells in combination with erlotinib. Int. J. Cancer 137, 1446-1456. doi: 10.1002/ijc.29483

Zhou, R., He, L. F., Li, Y. J., Shen, Y., Chao, R. B., and Du, J. R. (2012). Cardioprotective effect of water and ethanol extract of Salvia miltiorrhiza in an experimental model of myocardial infarction. J. Ethnopharmacol. 139, 440-446. doi: $10.1016 /$ j.jep.2011.11.030

Zhu, C., Dong, Y., Liu, H., Ren, H., and Cui, Z. (2017). Hesperetin protects against $\mathrm{H} 2 \mathrm{O} 2$-triggered oxidative damage via upregulation of the Keap1-Nrf2/HO1 signal pathway in ARPE-19 cells. Biomed. Pharmacother. 88, 124-133. doi: 10.1016/j.biopha.2016.11.089

Zhu, Y., Wang, L., Yang, Z., Wang, J., Li, W., Zhou, J., et al. (2016). Hematopoietic effects of paeoniflorin and albiflorin on radiotherapyinduced myelosuppression mice. Evid. Based Complement. Alternat. Med. 2016:5789381. doi:10.1155/2016/5789381

Zhu, Y.-L., Wang, L.-Y., Wang, J.-X., Wang, C., Wang, C.-L., Zhao, D.-P., et al. (2016). Protective effects of paeoniflorin and albiflorin on chemotherapyinduced myelosuppression in mice. Chin. J. Nat.l Medicines 14, 599-606. doi: 10.1016/S1875-5364(16)30070-X

Zielniok, K., Szkoda, K., Gajewska, M., and Wilczak, J. (2016). Effect of biologically active substances present in water extracts of white mustard and coriander on antioxidant status and lipid peroxidation of mouse $\mathrm{C} 2 \mathrm{C} 12$ skeletal muscle cells. J. Anim. Physiol. Anim. Nutr. 100, 988-1002. doi: 10.1111/jpn.12412

Conflict of Interest Statement: The authors declare that the research was conducted in the absence of any commercial or financial relationships that could be construed as a potential conflict of interest.

Copyright (๑) 2018 Zhang, Wang, Jia and Kong. This is an open-access article distributed under the terms of the Creative Commons Attribution License (CC BY). The use, distribution or reproduction in other forums is permitted, provided the original author(s) and the copyright owner(s) are credited and that the original publication in this journal is cited, in accordance with accepted academic practice. No use, distribution or reproduction is permitted which does not comply with these terms. 